\title{
Eosinophil Recruitment to the Lung in a Murine Model of Allergic Inflammation The Role of T Cells, Chemokines, and Adhesion Receptors
}

\author{
Jose-Angel Gonzalo, ${ }^{\star}$ Clare M. Lloyd, ${ }^{\star}$ Leonor Kremer,‡ Elizabeth Finger, ${ }^{\star}$ C. Martinez-A., ${ }^{\ddagger}$ M.H. Siegelman, ${ }^{\S}$ Myron Cybulsky, \\ and Jose-Carlos Gutierrez-Ramos* \\ *The Center for Blood Research, Inc. and The Department of Genetics, Harvard Medical School, Boston, Massachusetts; ${ }^{\ddagger}$ Centro \\ Nacional de Biotecnologia, CSIC, U.A.M. Madrid, Spain; ${ }^{\S}$ Department of Pathology, Southwestern Medical Center at Dallas, University

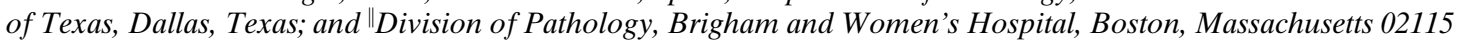

\section{Abstract}

Eosinophil accumulation is a distinctive feature of lung allergic inflammation. Here, we have used a mouse model of OVA (ovalbumin)-induced pulmonary eosinophilia to study the cellular and molecular mechanisms for this selective recruitment of eosinophils to the airways. In this model there was an early accumulation of infiltrating monocytes/macrophages in the lung during the OVA treatment, whereas the increase in infiltrating T-lymphocytes paralleled the accumulation of eosinophils. The kinetics of accumulation of these three leukocyte subtypes correlated with the levels of mRNA expression of the chemokines monocyte chemotactic peptide-1/JE, eotaxin, and RANTES (regulated upon activation in normal $\mathrm{T}$ cells expressed and secreted), suggesting their involvement in the recruitment of these leukocytes. Furthermore, blockade of eotaxin with specific antibodies in vivo reduced the accumulation of eosinophils in the lung in response to OVA by half. Mature $\mathrm{CD}^{+}$T-lymphocytes were absolutely required for OVA-induced eosinophil accumulation since lung eosinophilia was prevented in $\mathrm{CD}^{+}$deficient mice. However, these cells were neither the main producers of the major eosinophilic chemokines eotaxin, RANTES, or MIP-1 $\alpha$, nor did they regulate the expression of these chemokines. Rather, the presence of $\mathrm{CD}^{+} \mathrm{T}$ cells was necessary for enhancement of VCAM-1 (vascular cell adhesion molecule-1) expression in the lung during allergic inflammation induced by the OVA treatment. In support of this, mice genetically deficient for VCAM-1 and intercellular adhesion molecule-1 failed to develop pulmonary eosinophilia. Selective eosinophilic recruitment during lung allergic inflammation results from a sequential accumulation of certain leukocyte types, particularly $\mathrm{T}$ cells, and relies on the presence of both eosinophilic chemoattractants and adhesion receptors. (J. Clin. Invest. 1996. 98:2332-2345.) Key words: lung eosinophilia - leukocytes - chemotactic cytokines $\bullet$ integrins $\bullet$ selectins

Address correspondence to Dr. Jose-Carlos Gutierrez-Ramos, The Center For Blood Research Incorporated, Harvard Medical School, 200 Longwood Avenue, Boston, MA 02115. Phone: 617-278-3240; FAX: 617-278-3030; E-mail: gutierrez@cbrv1.med.harvard.edu

Received for publication 20 June 1996 and accepted in revised form 9 September 1996.

J. Clin. Invest.

(C) The American Society for Clinical Investigation, Inc. 0021-9738/96/11/2332/14 \$2.00

Volume 98, Number 10, November 1996, 2332-2345

\section{Introduction}

Lung eosinophilia is a fundamental trait of allergic asthma and infiltration of the airways by eosinophils appears to be central in the pathogenesis of this disease (1-3). The traffic of eosinophils to the sites of allergic reactions is presumed to be regulated at three distinct levels: $(a)$ adhesion receptors (selectins and integrins) that mediate transient or firm adhesion to inflamed vascular endothelium; $(b)$ activating factors (cytokines, chemokines, and chemoattractants) that induce expression of selectins and their ligands, and that activate eosinophil integrins and their endothelial counter-receptors, thus attracting this leukocyte subtype to the inflammatory site; and (c) leukocytes that are present at the inflammation site and which regulate the expression and release of these activating factors (4-9). Despite the fact that most molecules or cells involved at any of these three regulation levels are not eosinophil specific, they can provide sufficient combinatorial diversity to allow selective recruitment of eosinophils to the lung in vivo $(6,10)$.

Eosinophils express several adhesion receptors such as $\beta 1$ and $\beta 2$ integrins, E-selectin and P-selectin ligands (11), and L-selectin $(11,12)$. These surface molecules enable them to interact with the vascular endothelium. Eosinophil transendothelial migration in vitro can be partially inhibited by blocking the interactions of lymphocyte function-associated antigen 1 (LFA- 1$)^{1}$ and very late activation antigen 4 (VLA-4) with intercellular adhesion molecule 1 (ICAM-1), and vascular cell adhesion molecule 1 (VCAM-1) on endothelial cells, respectively $(4,5,13,14)$. Inhibition of this transmigration can be increased by blocking with an anti-E-selectin mAb (15). Recent in vivo experiments document that antigen-induced eosinophil infiltration of the mouse trachea is prevented by blocking VCAM-1-VLA-4, but not ICAM-1-LFA-1 interactions (16). In contrast, the in vivo administration of an anti-ICAM-1 $\mathrm{mAb}$ leads to decreased eosinophil infiltration and attenuated airway hyperreactivity in a primate model of chronic airway inflammation (17).

Chemoattractants, such as platelet activating factor and leukotriene B4, and several human chemokines, including monocyte chemotactic peptide 3 (MCP-3), macrophage in-

1. Abbreviations used in this paper: BAL, bronchoalveolar lavage; ICAM-1, intercellular adhesion molecule-1; LFA-1, lymphocyte function-associated antigen 1; MCP, monocyte chemotactic peptide; MIP, macrophage inflammatory protein; OVA, ovalbumin; RANTES, regulated upon activation in normal $\mathrm{T}$ cells expressed and secreted; VCAM-1, vascular cell adhesion molecule-1; VLA-4, very late activation antigen 4; wt, wild-type. 
flammatory protein $1 \alpha$ (MIP- $1 \alpha)$, and regulated upon activation in normal $\mathrm{T}$ cells expressed and secreted (RANTES) have been reported to elicit significant migration of eosinophils (11, 18, 19). Recently, eotaxin, a chemokine that is highly efficient in inducing migration of eosinophils, has been identified and extensively studied in guinea pigs $(20,21)$, mice $(22,23)$, and humans (24).

Pathological processes that result in lung eosinophilia may involve antigen-induced $\mathrm{T}$ cell activation through macrophages or other antigen presenting cells, T cell cytokine release, specific sensitization of mast cells, and release of activating mediators by macrophages (8). Macrophages are able to amplify the inflammatory response and to increase eosinophil proliferation and survival by virtue of their potential to generate a variety of proinflammatory mediators and cytokines (25-28).

There is a strong correlation between the level of cytokines released by activated $\mathrm{T}$ cells and the degree of eosinophilmediated tissue damage in the lung $(29,30)$. Eosinophils and lymphocytes tend to appear in certain types of inflammatory lesions in the absence of a marked neutrophilic infiltration $(31,32)$. Indeed, the accumulation of eosinophils at sites of allergic reactions has been directly correlated with the production of T cell cytokines such as IL-5, IL-3, and GM-CSF, which are known to stimulate eosinophil maturation, activation, and survival (33-36) and IL-4, which enhances the endothelial expression of VCAM-1 (37-40). VCAM-1 upregulation may augment the migration of eosinophils but not of neutrophils, which lack VLA-4 (14).

Selective activation of adhesion molecules on eosinophils and endothelial cells by leukocyte cytokines (IL-4, IL-1 $\beta$, TNF- $\alpha)(15,39,41)$ and production of eosinophilic chemokines (RANTES, eotaxin) by different cell types $(23,42)$ could promote eosinophil migration and their subsequent accumulation in the tissue. Cooperation between these groups of mediators has been demonstrated during in vivo recruitment of eosinophils (43).

The molecular cloning and functional characterization of the leukocyte integrins, their endothelial Ig gene superfamily ligands, and of selectins has made it possible to construct mutant mice to address the roles of these molecules in different pathological situations in vivo $(44,45)$. This, together with the identification and cloning of specific chemokines, facilitates the determination of the molecular and cellular basis of migration of different leukocytes and its regulation during inflammation. Here, using a mouse model of lung eosinophilia in vivo based on the repeated exposure of mice to aerosolized ovalbumin (OVA) (23), we analyze (a) the kinetics of accumulation in the lung of several leukocyte subtypes during the OVA treatment; $(b)$ the correlation between the accumulation of specific leukocyte subtypes and the expression of several chemokines (RANTES, eotaxin, MCP-1/JE, MIP-1 $\alpha$, and TCA-3) in eosinophilic lungs; $(c)$ the effects of the blockade of eotaxin in vivo on the kinetics of accumulation of eosinophils; $(d)$ the specific role of $\mathrm{B}-, \mathrm{CD}^{+}-$and $\mathrm{CD}^{+}-\mathrm{T}$-lymphocytes during lung eosinophilia by studying the response to the OVA treatment in mice lacking these leukocyte subtypes; $(e)$ changes in the expression of these chemokines and adhesion receptors in the absence of these lymphocyte subtypes during lung eosinophilia in vivo; and $(f)$ the contribution of the individual adhesion receptors ICAM-1, VCAM-1, P-selectin, and L-selectin to the eosinophil accumulation in this model by using mice that have been made genetically deficient in these molecules.

\section{Methods}

Mice and in vivo procedures. $8-10$-wk-old male and female C57BL/ $6 \mathrm{~J}$, RAG-1, and P-selectin-deficient mice were purchased from the Jackson Laboratory (Bar Harbor, ME) and kept in the Center for Blood Research Specific Pathogen Free mouse facility. CD4- and CD8-deficient mice $(46,47)$ were provided by Dr. Tak W. Mak (AMGEN Institute, Toronto, Canada), and CD3€ transgenic mice (48) were kindly provided by Dr. C. Terhorst (Beth Israel Hospital, Boston, MA). L-selectin-deficient mice were generated and provided by Dr. M. Siegelman. Since VCAM-1-null mutant mice are embryonic lethal (49), VCAM-1-hypomorphic mutant mice were used for these studies (50). These mutant mice were generated by a targeted deletion in domain 4 of the VCAM-1 molecule (which eliminates the main $\alpha 4$ integrin binding site). The mRNA level of the truncated VCAM-1 molecule in the hypomorphic mutants used here is $95 \%$ reduced compared to wild type (wt) levels (50 and not shown). Also, the affinity of the remaining truncated VCAM- 1 to $\alpha 4$ integrins is presumably greatly diminished as shown previously in vitro (51). ICAM-1-deficient mice were previously generated by us (52). Mice designated as wt in the results section are littermates of these mutants that have a mixed genetic background $129 \mathrm{sv} \times \mathrm{C} 57 \mathrm{BL} / 6 \mathrm{~J}$. Pulmonary eosinophilia in response to OVA (Sigma Chemical Co., St. Louis, MO) was generated in these groups of mice as described (23). The murine model of lung eosinophilia used here consists of an initial phase of sensitization and a second phase of induction of the response. Thus, mice were sensitized with intraperitoneal OVA $(0.1$ $\mathrm{mg} / \mathrm{mouse}$ ) on day 1 followed by exposure to aerosolized antigen ( $2 \%$ OVA for $5 \mathrm{~min}$ on day 8 and 1\% OVA for $20 \mathrm{~min}$ on days 15-21) to induce the response. At different times after allergen challenge, animals were killed by barbiturate overdose and analyzed. PBS (intraperitoneal and aerosolized) was administered to mice as a negative control. The following number of mice of the indicated strains were used per time point in three individual experiments: 10,4 , and 4 C57BL/6J mice per time point for experiments shown in Figs. 1, 4 A, and 6, respectively; 4 RAG-1, CD4 and CD8-deficient mice, and 4 $\mathrm{CD} 3 \epsilon$ transgenic mice per time point for experiments shown in Fig. 4 $A$; 4 ICAM-1, VCAM-1, and P-selectin-mutant mice and 3 L-selectin-mutant mice per time point for experiments shown in Fig. 6. In one series of blocking experiments, mice were injected with neutralizing polyclonal Abs against murine eotaxin $(20 \mu \mathrm{g} / \mathrm{mouse}$, i.v. $) 30 \mathrm{~min}$ before OVA administration on days 20 and 21 and then analyzed $3 \mathrm{~h}$ after allergen challenge on day 21. OVA-treated control mice were injected with the same amount of control $\mathrm{Ab}$ (rabbit immunoglobulin fraction; Dako Corp., Santa Barbara, CA) at the same time points indicated during treatment. No endotoxin contamination was detected in all reagents used, as assessed by LAL assay (BioWhittaker, Walkersville, MD).

Bronchoalveolar lavage (BAL) was essentially performed as described (23). Briefly, at the different time points indicated after the last aerosol exposure, the airways of the mice were lavaged via a tracheal cannula with $1 \mathrm{ml}$ of PBS. The resulting BAL fluid was immediately centrifugated $\left(700 \mathrm{~g}, 5 \mathrm{~min}, 4^{\circ} \mathrm{C}\right)$ and $\mathrm{BAL}$ cells were then washed twice and resuspended in $1 \mathrm{ml}$ of PBS.

Immunohistochemical phenotyping and quantitation of leukocytes. The number and type of leukocytes were determined in lung sections and BAL fluid. Excised lungs from OVA-treated mice were obtained at the indicated time points, fixed in $10 \%$ formalin, embedded in paraffin (Tissue-Tek, Miles Inc., Somerset, MA), and sectioned at $5 \mu \mathrm{m}$ on a microtome (Reichert-Jung, Vienna). To determine the number of eosinophils, a sensitive method dependent on the presence of a cyanide-resistant endogenous peroxidase was used (23).

To determine the number of lymphocytes, macrophages, and neutrophils and to analyze the expression of ICAM-1 and VCAM-1 protein, remaining portions of the excised lungs were rolled in Tissue Tek OCT compound (Cryoform, IEC, Needham Heights, MA), snap frozen in liquid nitrogen and stored at $-70^{\circ} \mathrm{C}$. Cryosections $(4 \mu \mathrm{m})$ were cut onto microscope slides, dried for $2 \mathrm{~h}$, and fixed for $20 \mathrm{~min}$ in 
acetone at $4^{\circ} \mathrm{C}$. Fixed sections were stained with $\mathrm{mAb}$ directed against Thy 1.2 (53-2.1), Mac-1 (M1/70), GR.1 (RB6-8C5), and IgM (II/41) from PharMingen (San Diego, CA) and ICAM-1 (YN1/1.7.4) and VCAM-1 (mK2.2) kindly provided by Drs. Springer and Lobb, respectively, using an avidin/biotin staining method. All incubations were carried out under humidified conditions and slides were washed between steps (twice for 5 min each in $0.1 \mathrm{M}$ phosphate buffered saline, $\mathrm{pH}$ 7.4). Sections were overlaid with $20 \%$ fetal calf serum in PBS for $15 \mathrm{~min}$ and incubated for $1 \mathrm{~h}$ at room temperature with the $\mathrm{mAbs}$ described above. Bound ab was visualized by incubation with biotinylated sheep anti-rat immunoglobulin (Dako Corp.) and then with streptavidin peroxidase complex (Dako Corp.) both diluted in 1\% normal mouse serum/PBS (NMS/PBS), and incubated for $30 \mathrm{~min}$. Finally slides were flooded with peroxidase substrate solution $(400 \mathrm{mg}$ diaminobenzidine in $10 \mathrm{ml}$ of PBS, containing $0.01 \%$ hydrogen peroxide) for $10 \mathrm{~min}$. Control sections were included where $\mathrm{mAb}$, biotinylated anti-rat immunoglobulin or streptavidin complex were selectively omitted.

Number of leukocyte subtypes was determined in four high power fields (at a magnification of 40; total area $0.5 \mathrm{~mm}^{2}$ ) per section (duplicate sections per mouse and time point were examined). These high power fields were selected randomly under a low power of magnification $(\times 4)$ at which leukocyte subtypes were not visible and compared with the number of leukocytes present in control mice.

To determine the number and type of leukocytes in the BAL fluid, samples were applied to glass slides by cytocentrifugation $\left(5 \times 10^{5}\right.$ cells/slide), air dried for $10 \mathrm{~min}$ and then immersed in Wright-Giemsa stain (Fisher Diagnostics, Pittsburgh, PA), rinsed with distilled water, air dried, and mounted. Percentage of eosinophils, lymphocytes, neutrophils, and macrophages was determined by counting their number in eight high power fields (at a magnification of 40 ; total area 0.5 $\mathrm{mm}^{2}$ ) per area selected by the same criteria as above and dividing this number by the total number of cells per high power field. To obtain the absolute number of each leukocyte subtype in the lavage, these percentages were multiplied by the total number of cells recovered from the BAL fluid.

Measurement of $m R N A$ expression by Northern blots. Total RNA from eosinophilic lungs of OVA-sensitized wt mice $(1,3$, and $6 \mathrm{~h}$ after treatment on days 15, 18, and 21) and from lungs of OVA-treated mutant mice ( $3 \mathrm{~h}$ after challenge on days 15,18 , and 21) was isolated using the guanidinium thiocyanate/acid phenol procedure (53). RNA from lungs of PBS-treated mice at the same time points was used as a control. Northern blots (54) were performed with $20 \mu \mathrm{g}$ of total RNA indicated above, fractionated in a $1.5 \%$ agarose/formaldehyde gel, and blotted onto a nylon membrane (Genescreen; DuPont, Willmington, DE). Membranes were probed using ${ }^{32} \mathrm{P}$-labeled mouse probes for eotaxin (23), RANTES (55), MCP-1/JE (56), MIP-1 $\alpha$ (57), and TCA-3 (58) applied in 50\% formamide hybridization solution at $42^{\circ} \mathrm{C}$ for $18 \mathrm{~h}$. Blots were washed in $2 \times \mathrm{SSC} / 1 \%$ SDS at $45^{\circ} \mathrm{C}$ and exposed at $-70^{\circ} \mathrm{C}$ on Kodak XAR5 film.

Anti-eotaxin antibody generation. Polyclonal Abs against murine eotaxin were prepared according to standard methods (59). Briefly, $100 \mu \mathrm{g}$ of purified recombinant eotaxin (23) were inoculated into rabbits together with complete Freund's adjuvant and challenged at different time points after immunization. Ab titers were determined in an ELISA using recombinant meotaxin as immobilized antigen. Rabbit serum was first depleted of antihuman $\operatorname{IgG}$ Abs by passage over a human IgG column and anti-meotaxin Abs were purified from the flow through on a meotaxin affinity column. Bound $\mathrm{Ab}$ were eluted with $0.1 \mathrm{~mol} / \mathrm{liter}$ acetic acid/ $/ .12 \mathrm{~mol} / \mathrm{liter} \mathrm{NaCl}(\mathrm{pH}, 3.0)$, immediately neutralized with $1 \mathrm{~mol} /$ liter Tris $(\mathrm{pH}, 8.8)$, dialyzed against three changes of PBS, and stored at $-70^{\circ} \mathrm{C}$ in $10 \%$ glycerol/PBS.

For production of mAbs against eotaxin 10-wk-old Wistar rats were immunized in the hind footpad with KLH-coupled recombinant eotaxin using a standard protocol used by us previously (60). $8 \mathrm{~d}$ after immunization popliteal lymph nodes were removed and fused with the murine plasmacytoma P3X63Ag8.653 (60). 12 d after fusion, supernatants from growing wells were screened by ELISA for the presence of anti-eotaxin Abs. Positive supernatants were studied in Western blot analysis against eotaxin produced by transfected cells. Positive hybridomas were stabilized by limiting dilution using BALB/c mouse thymocytes as a feeder layer until stable $\mathrm{Ab}$ production was achieved.

Affinity purified rabbit polyclonal Abs and rat mAbs were shown to recognize a specific band in a Western blot against eotaxin-containing supernatant but not against the supernatant of mock-transfected cells (data not shown).

Determination of eotaxin protein expression within lung tissue. The level of expression of eotaxin protein was determined in sections from lungs of OVA-treated mice and controls. Sections were prepared as detailed above and staining was accomplished using a modified avidin/biotin staining method. All incubations were carried out under humidified conditions and slides were washed twice between steps for 5 min each in $0.1 \mathrm{M}$ PBS supplemented with $0.2 \%$ gelatin (PBSG). Sections were overlaid with $20 \%$ normal rabbit serum in PBS for $15 \mathrm{~min}$ and then incubated overnight at $4^{\circ} \mathrm{C}$ with monoclonal anti-eotaxin diluted $1: 2$ in PBS with $0.1 \%$ BSA and $0.1 \%$ sodium azide. Endogenous peroxide was subsequently blocked by incubation for $20 \mathrm{~min}$ in methanol containing $0.3 \%$ hydrogen peroxide. Non-specific staining due to cross reaction with endogenous avidin or biotin was blocked by incubation with avidin solution followed by biotin solution, both for $20 \mathrm{~min}$. Bound monoclonal $\mathrm{Ab}$ was visualized by incubation with biotinylated rabbit anti-rat immunoglobulin diluted in $10 \%$ normal mouse serum PBS, and then streptavidin peroxidase complex prepared according to manufacturer's instructions (both from Dako Corp.), and incubated for $1 \mathrm{~h}$ each. Finally, slides were flooded with peroxidase substrate solution ( $20 \mathrm{mg}$ diaminobenzidine in $10 \mathrm{ml}$ PBS, containing $0.01 \%$ hydrogen peroxide) for $10 \mathrm{~min}$ before counter staining with hematoxylin. Control slides were either stained with an irrelevant $\mathrm{Ab}$ (anti-TR5) (61) or biotinylated anti-rat immunoglobulin or streptavidin complex were selectively omitted.

\section{Results}

Characterization of leukocyte accumulation in the mouse lung in response to $O V A$. To characterize leukocyte types recruited to lung airways and parenchyma after antigen challenge, as well as their time of arrival to this organ, preimmunized mice (day 1) were challenged with repeated aerosolized exposure to OVA (days 8 and 15-21). At different time points (0, 1, 3, 6, and $12 \mathrm{~h}$ ) after exposure to OVA on days 15,18 , and 21 of treatment, leukocytes present in the BAL fluid and in the lung parenchyma were ennumerated (Fig. 1). Analysis of the pulmonary infiltration at these two levels (in the airways by BAL or in the parenchyma by counting leukocytes in the tissue) demonstrated a marked increase in the total number of leukocytes present in this tissue. We have previously characterized the kinetics of lung eosinophil accumulation in this model (23). Briefly, a progressive increase in the number of eosinophils is detected in lung tissue and BAL, reaching a maximum level at day 21 of treatment. Each day after OVA administration there is a transient increase in BAL and tissue eosinophils which is maximal at $3 \mathrm{~h}$. Kinetics of eosinophil infiltration are shown in the bottom of Fig. 1 for comparison with the other leukocyte subtypes. Lymphocyte accumulation in BAL and lung tissue follows a similar profile to that of eosinophils, in that within 6-12 h after OVA challenge on day 15, we detected a fivefold increase in the number of T-lymphocytes in lung tissue (Fig. 1). On days 18 and 21 of OVA treatment, a progressive increase in tissue infiltrating T-lymphocytes was evident. This increase peaks at $3 \mathrm{~h}$ at both time points and constitutes 20 - and 25-fold for T-lymphocytes on days 18 and 21, respectively, and is readily detectable within $1 \mathrm{~h}$ after the OVA inhalation. The 


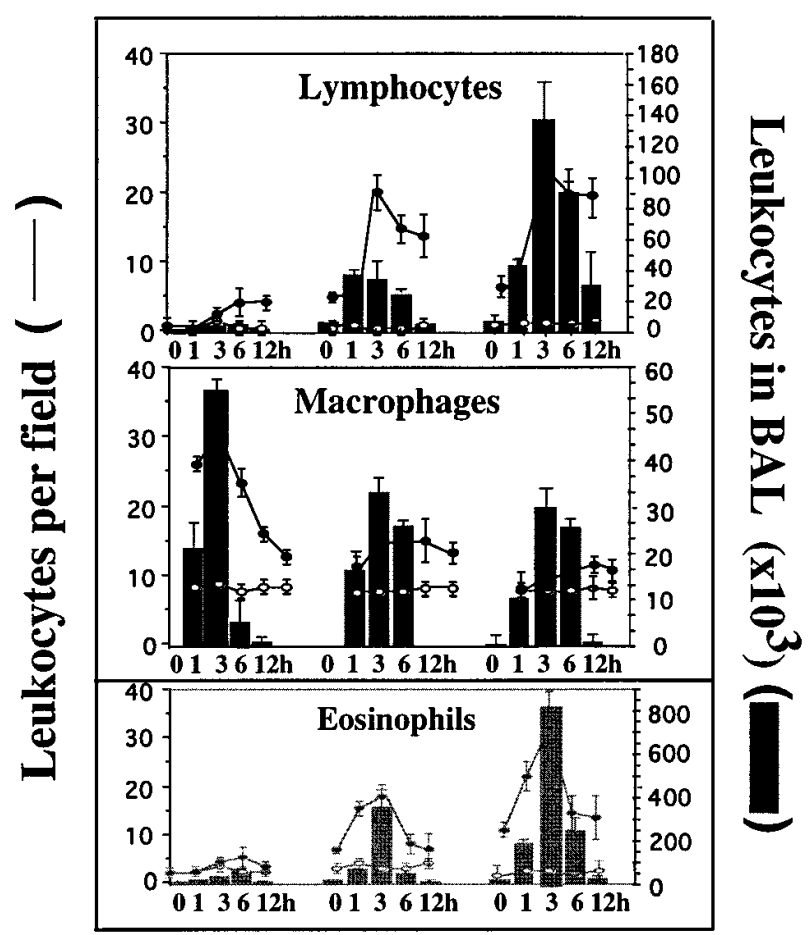

day 15 day 18 day 21

Figure 1. Pulmonary accumulation of lymphocytes and monocytes/ macrophages in response to OVA treatment. Lymphocyte and macrophage infiltration in lung sections (dots) and BAL fluid (bars) are shown on days 15,18 , and 21 of OVA treatment at the different time points indicated. The treatment is described in detail in the Methods section. Solid circles and open circles represent the numbers of the indicated cell types counted in lung sections of experimental and control mice, respectively. The kinetics of eosinophil accumulation at the same time points is shown for comparison in the figure. Error bars indicate the standard deviation of the average of each cell type counted in four high power fields per lung in 3 individual experiments with 10 OVA-treated mice per time point and experiment. Total number of eosinophils, lymphocytes, and monocytes/macrophages in the BAL fluid was calculated as the product of the total cellularity of the BAL and the percentage of each cell type. Each value was corrected for background by subtracting values of control mice from OVA-treated littermates.

number of lymphocytes present in the BAL fluid also increases during the course of this treatment and becomes maximal $3 \mathrm{~h}$ after OVA administration on day 21 (15-fold increase; Fig. 1). It should be noted that $12 \mathrm{~h}$ after OVA administration, the number of total lymphocytes in BAL fluid decreases to almost basal levels while tissue infiltrates (perivascular and peribronchiolar) remain well above basal levels in the lung (as was observed for eosinophils).

The kinetics of macrophage accumulation in the lung during the response to OVA is inverse to that described above for eosinophils and lymphocytes. Macrophage accumulation peaks $3 \mathrm{~h}$ after OVA administration on day 15 by $3-4$-fold in lung tissue and by 50 -fold in BAL fluid (Fig. 1). Increased numbers of macrophages were also observed in both lung tissue and $\mathrm{BAL}$ fluid on days 18 and 21 although to a lesser degree than on day 15. At all time points examined the number of infiltrating macrophages decreases almost to basal levels by $12 \mathrm{~h}$ after last OVA administration.
No significant and persistant increase in neutrophil, B-lymphocyte, and mast cell numbers was detected during the course of this treatment when OVA and control mice were compared (data not shown).

Chemokine expression during the development of OVAinduced lung eosinophilia. Since chemokines are important inflammatory mediators involved in the recruitment and activation of leukocytes at sites of inflammation, we tried to correlate OVA-induced eosinophil, T-lymphocyte, and macrophage accumulation with the expression of chemokines specific for these cell subtypes. We assessed the expression of mRNA for murine RANTES $\left(\mathrm{CD}^{+} \mathrm{T}\right.$ cell and eosinophil chemoattractant) (62), MCP-1/JE, (macrophage chemoattractant) (63), MIP- $1 \alpha$ (monocyte and eosinophil chemoattractant) $(64,65)$, TCA-3 (neutrophil and monocyte chemoattractant) (66), and eotaxin (eosinophil chemoattractant) (23) during lung eosinophilia. Northern blots of total RNA isolated from lungs of OVA-treated mice on days 15,18 , and $21(1,3$, and $6 \mathrm{~h}$ after OVA inhalation) revealed a comparable pattern of RANTES and eotaxin mRNA expression (Fig. $2 A$ ). Induction of MCP$1 / \mathrm{JE}$ mRNA in response to OVA challenge was maximal at $3 \mathrm{~h}$ after OVA-administration on day 15 of treatment. On the same day, $6 \mathrm{~h}$ after antigen challenge significant MCP-1/JE mRNA expression was still detectable. On days 18 and 21, Northern blot analyses revealed a transient increase in MCP-1/ JE mRNA expression detected $3 \mathrm{~h}$ after OVA administration (Fig. 2 A). The mRNA expression of TCA-3 was virtually undetectable during the course of this treatment and there was no discernible increase at any time point after OVA challenge (Fig. $2 A$ ). Finally, the pattern of mRNA expression for MIP-1 $\alpha$ was not distinguishable from that described above for RANTES or eotaxin (Fig. $2 A$ ).

Among the chemokines examined above, eotaxin is the most selective regarding the chemoattraction of eosinophils $(20,67)$. In addition, its transcription profile correlates well with the accumulation of eosinophils in vivo. To determine the predominant cell type(s) producing eotaxin in this model and the relevance of eotaxin expression in the accumulation of eosinophils in vivo, we generated Abs against eotaxin. The

Table I. Properties of a Panel of Anti-meotaxin mAbs

\begin{tabular}{ccccc}
\hline mAb & ELISA & Western blot & $\begin{array}{c}\text { Staining } \\
\text { lung sections* }\end{array}$ & $\begin{array}{c}\text { Neutralizing } \\
\text { activity }\end{array}$ \\
\hline mEOT-1 & + & ++ & ++ & ND \\
mEOT-2 & + & ++ & ++ & ND \\
mEOT-3 & + & + & - & ND \\
mEOT-4 & + & - & - & ND \\
mEOT-5 & + & ++ & ++ & ND \\
mEOT-6 & + & ++ & ++ & ND \\
mEOT-7 & + & ++ & ++ & ND \\
mEOT-8 & + & + & - & ND \\
mEOT-9 & + & + & - & ND \\
polyEOT & + & ++ & ND & + \\
& & & &
\end{tabular}

* Immunohistochemical staining was performed as described in Methods using lungs from OVA-treated mice. ${ }^{\ddagger}$ Neutralizing activity of the antieotaxin polyclonal antibody was assessed previously in vitro by transmigration experiments (97\% blocking). $(++$ and +$)$ Strong and weak reactivity in Western blots and immunohistochemistry. (-) No staining. (ND) Not determined. 


\section{Day 15 Day 18 Day 21

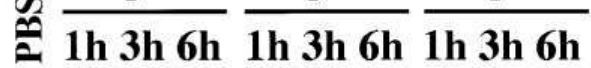

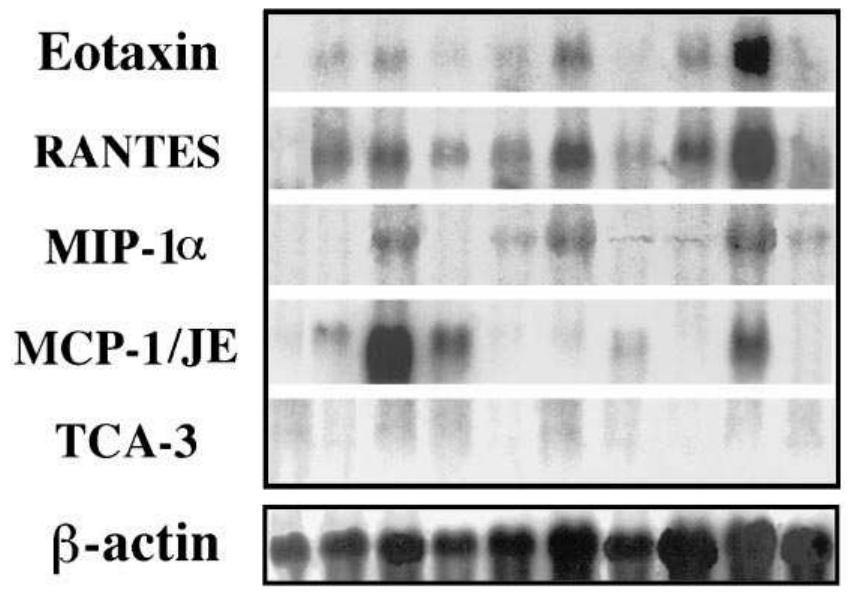

Figure 2. Chemokine expression during lung eosinophilia. $(A)$ Expression of eotaxin, RANTES, MIP- $1 \alpha$, MCP-1/JE, and TCA-3 mRNAs in the lung during OVA treatment. On days 15,18 , and 21 , total RNA from lungs of OVA-treated mice was extracted 1,3, and $6 \mathrm{~h}$ after antigen administration. In a control group, mice were treated with aerosolized PBS instead of OVA. Eotaxin, RANTES, MCP-1/JE, MIP- $1 \alpha$, and TCA-3 mRNA induction was determined by Northern blot. Chemokine expression of one representative mouse out of four is showed. Lower panel shows a control hybridization of the blot with a $\beta$-actin probe. (B) Immunohistochemical staining of lung sections from OVA-treated mice on day $21,3 \mathrm{~h}$ after OVA inhalation $(I, I I$, and $I V$ ) and a PBS control (III). Sections were stained with antieotaxin mAb (mEOT-1) (see Methods) (II, III, and $I V$ ) or a negative control isotype matched $\mathrm{mAb}(I)$. Note that positive staining, seen as a brown precipitate, is not detected in infiltrating cells (arrowheads) but is observed in resident lung cells, in particular the alveolar endothelium (arrows). $\times 1,000$.

B
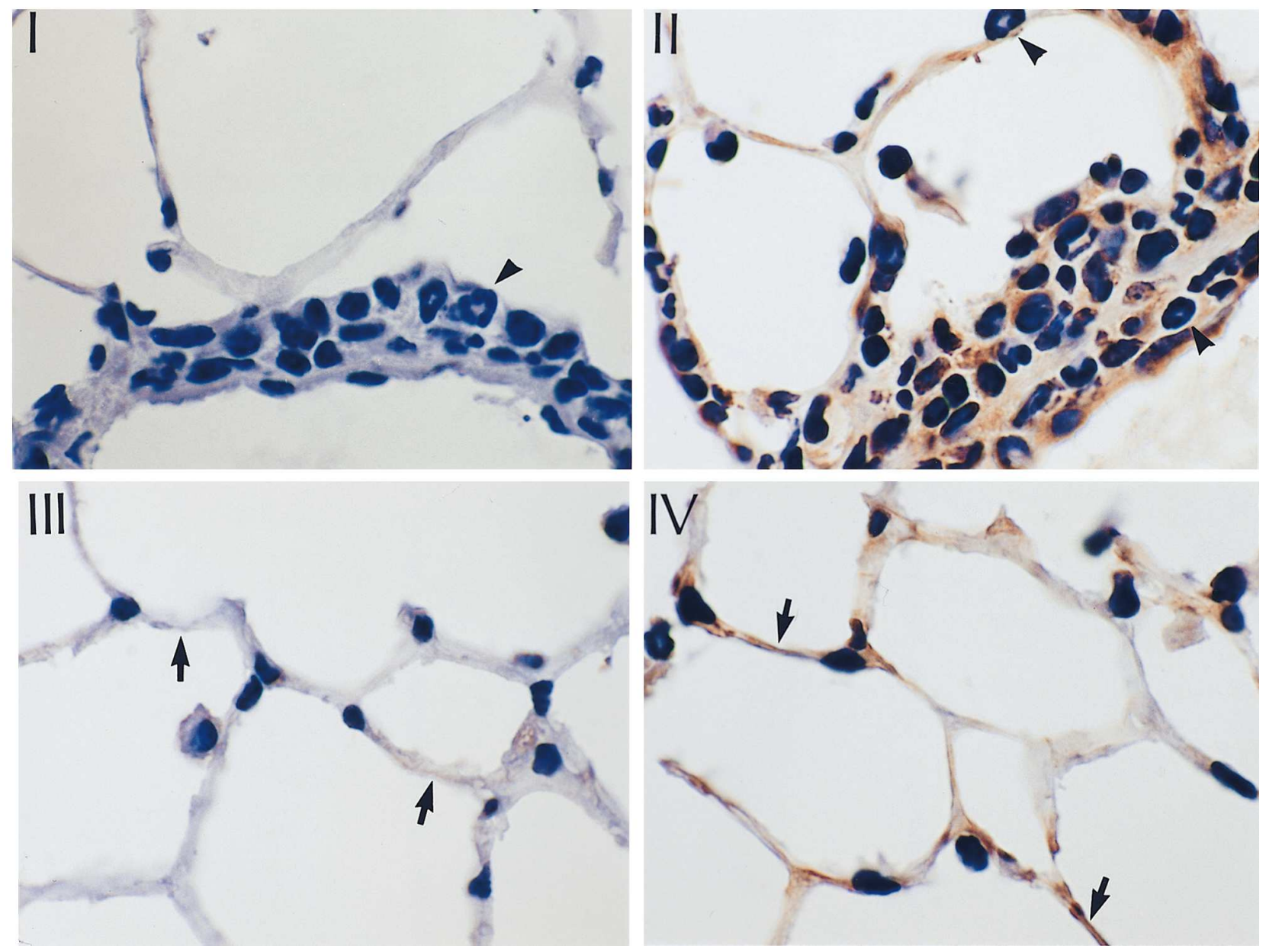

properties of nine selected $\mathrm{mAbs}$ and one polyclonal $\mathrm{Ab}$ are outlined in Table I. All these Abs were determined to be specific for eotaxin by ELISA. Five of the eotaxin specific mAbs showed strong reactivity in Western blots and were able to recognize an epitope of mouse eotaxin that is preserved in frozen sections of lung. The anti-eotaxin polyclonal $\mathrm{Ab}$ was noted for

its ability to block the in vitro transmigration of eosinophil to eotaxin by $97 \%$ (Table I and data not shown). Neutralizing properties of mAbs are currently being investigated. Immunohistochemical analysis of eotaxin protein expression in sections of eosinophilic lungs from OVA-treated mice was performed. Our results show that most of the eotaxin protein expressed 


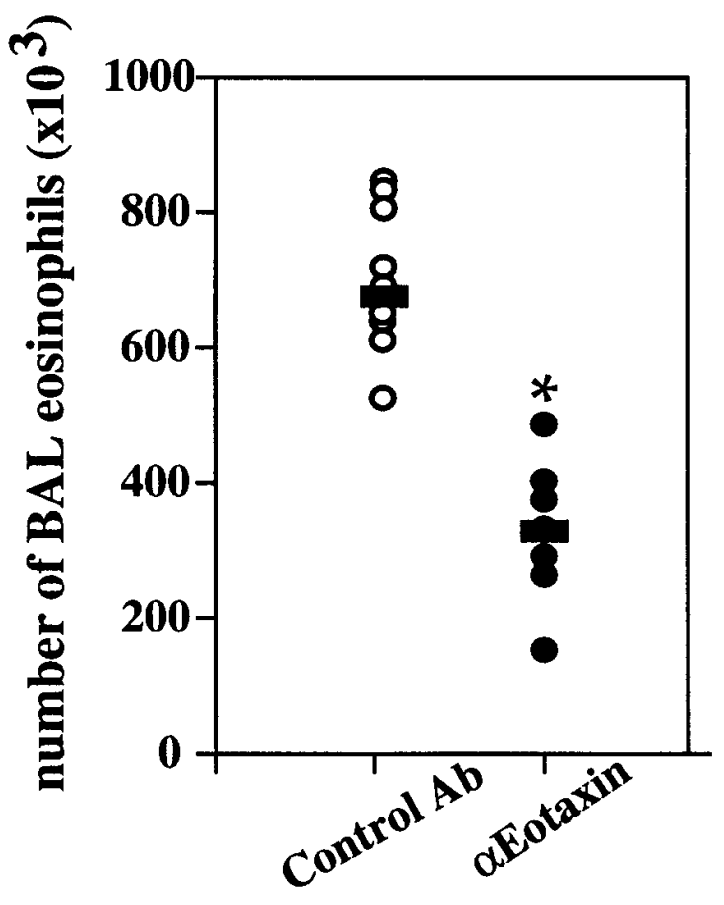

Figure 3. In vitro blockade of eotaxin with specific neutralizing Abs during OVA-induced eosinophilia. $30 \mathrm{~min}$ before antigen challenge on the last two days of OVA treatment, mice were injected with neutralizing Abs against eotaxin as described in the Methods section. OVA-treated control mice were injected with control $\mathrm{Ab}$ at the same time points indicated. BAL fluid was obtained $3 \mathrm{~h}$ after OVA treatment on day 21 and number of eosinophils was determined. Each circle represents a single control mouse (open circle) or a single test mouse (closed circle) analyzed. Bars represent the mean of each group. Significant difference between groups was determined using the Student's $t$ test $(* P<0.001)$.

can be attributed to resident lung cells (Fig. 2 B). In particular, increased expression was observed in alveolar epithelial cells after OVA treatment confirming our previous data obtained by in situ hybridization (23). Few, if any, of the leukocytes that constitute perivascular infiltrates (mainly eosinophils and lymphocytes) showed positive staining at late stages of OVAinduced eosinophilia (Fig. $2 \mathrm{~B}$ ).

To determine the particular contribution of eotaxin to the development of OVA-induced lung eosinophilia, blocking experiments in vivo with anti-eotaxin polyclonal Abs were performed. Intravenous administration of anti-eotaxin Abs resulted in a $56 \%$ reduction of eosinophils in BAL when compared with OVA-treated control mice (Fig. 3).

Role of lymphocytes in pulmonary eosinophilia: response of mice with selective immunodeficiencies to $O V A$. In the light of the distinct kinetics of lymphocyte and macrophage accumulation in this model and, particularly of the parallel kinetics of eosinophil and lymphocyte accumulation, we evaluated the contribution of these cell types to the induction of eosinophilia in vivo. To dissect the specific role that different lymphocyte subtypes may play in the accumulation of eosinophils in this model, we studied the response of RAG-1-deficient mice ( $\mathrm{T}$ and B cell-deficient) (68) and CD3€ transgenic mice ( $\mathrm{T}$ and NK cell-deficient)(48), as well as mice lacking either $\mathrm{CD}^{+}$or $\mathrm{CD}^{+}$T-lymphocytes $(46,47)$ to the OVA treatment. $3 \mathrm{~h}$ after OVA challenge on day 21, BAL fluid from these immunodefi- cient mice was obtained and leukocyte subtypes were enumerated. Fig. $4 A$ shows that there is almost a complete reduction in the number of infiltrating eosinophils recovered from the BAL fluid of OVA-treated RAG-1-deficient mice and CD3є transgenic mice when compared with OVA-treated wt littermates. We observed a small but detectable population of lymphocytes (1/20 of that found in wt mice) in the BAL fluid of $\mathrm{CD} 3 \epsilon$ transgenic mice at the same time point analyzed (Fig. 4 $A)$. To further investigate whether $\mathrm{CD}^{+}$and/or $\mathrm{CD}^{+}$T-lymphocytes are both required for the induction of eosinophilia in this model, mice lacking either $\mathrm{CD}^{+}$or $\mathrm{CD} 8^{+} \mathrm{T}$-lymphocytes were also examined (Fig. $4 A$ ). We observed a comparable reduction of eosinophils in the BAL of CD4-deficient mice to that found in RAG-1-deficient mice or CD3€ transgenic mice. In contrast, CD8-deficient mice subjected to the same treatment showed no significant changes in BAL eosinophilia when compared to OVA-treated wt littermates (Fig. $4 A$ ). In addition, a similar degree of lymphocyte infiltration was found in wt and CD8-deficient mice (Fig. $4 A$ ) suggesting that a significant fraction of the infiltrating lymphocytes belong to the $\mathrm{CD}^{+}$lineage $(\sim 70 \%$, as shown by the numbers of lymphocytes in CD4-deficient mice, Fig. $4 A$ ). The number of macrophages (Fig. $4 A$ ) and neutrophils (data not shown) recovered from the BAL fluid of these mutant mice remained comparable to their corresponding wt littermates at this time point of the OVA treatment. Similarly, maximal macrophage accumulation occurred on day 15 in both groups of mice (data not shown).

To exclude the chance that cells might have migrated into the interstitium but not progressed into the airways in the absence of $\mathrm{CD}^{+}{ }^{+} \mathrm{T}$ cells, lung sections from OVA-treated RAG-1, and CD4-deficient mice (3 $\mathrm{h}$ after OVA challenge on day 21) were prepared and the number of eosinophils in the parenchyma was counted. No eosinophil infiltration was detected in the lungs of these mutant mice when compared with wt or CD8-mutant mice (data not shown and Figs. $4 C$, and 5).

To rule out the possibility that pulmonary eosinophil accumulation in response to OVA was delayed rather than abrogated in RAG-1 and CD4-deficient mice, BAL fluid obtained $7 \mathrm{~h}$ after OVA administration on day 21 was analyzed. As was detected at the $3 \mathrm{~h}$ time point, no eosinophil infiltration was seen at this later time point in these mutants (data not shown). Wt and CD8-mutant mice showed similar numbers of infiltrating eosinophils at this time point (data not shown). To exclude the possibility that prevention of lung eosinophilia after exposure to OVA in these mutant mice was due to impaired bone marrow eosinophil differentiation resulting from an intrinsic lack of IL-5-producing CD4 ${ }^{+} \mathrm{T}$ cells, IL-5 was intravenously administered and $1 \mathrm{~h}$ later, numbers of eosinophil recovered from the blood of the different IL-5-treated mutant mice were determined. No differences were detected in the number of circulating eosinophils shortly after IL-5 injection in mutant mice that did not develop OVA-induced BAL eosinophilia (i.e., CD4 or RAG-1-mutant mice) when compared with those found in wt and CD8-deficient mice (data not shown). To exclude the possibility that functional differentiation of eosinophils was affected in CD4-deficient mice, IL-5 was administered both intravenously and intraperitoneally daily over $1 \mathrm{wk}$. $2 \mathrm{~h}$ after the final IL-5 injection, eosinophil accumulation into the peritoneum of these treated CD4-deficient mice was evaluated. Peritoneal eosinophilia was not impaired in these mutant mice when compared with wt littermates (data not shown). 
A
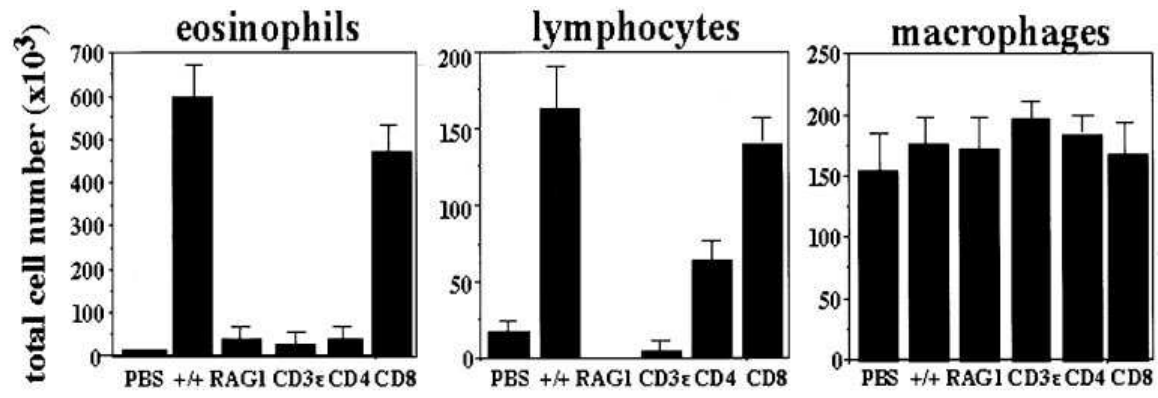

B

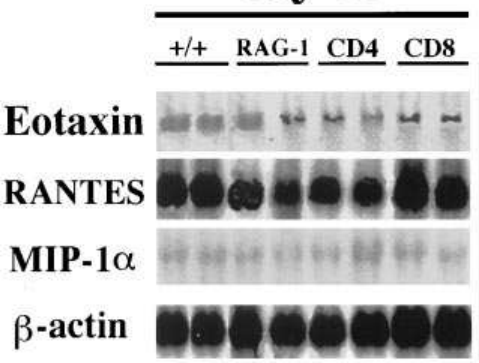

day 15

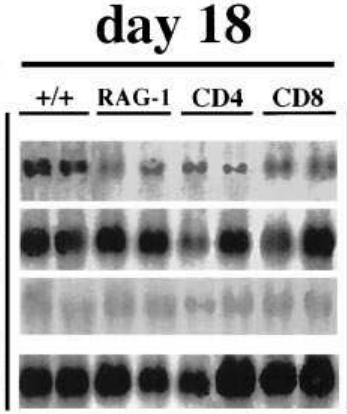

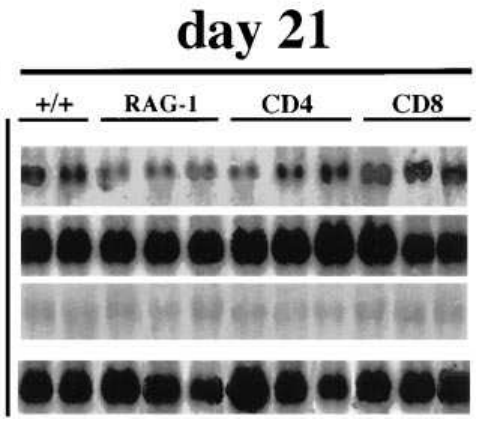

\section{C}

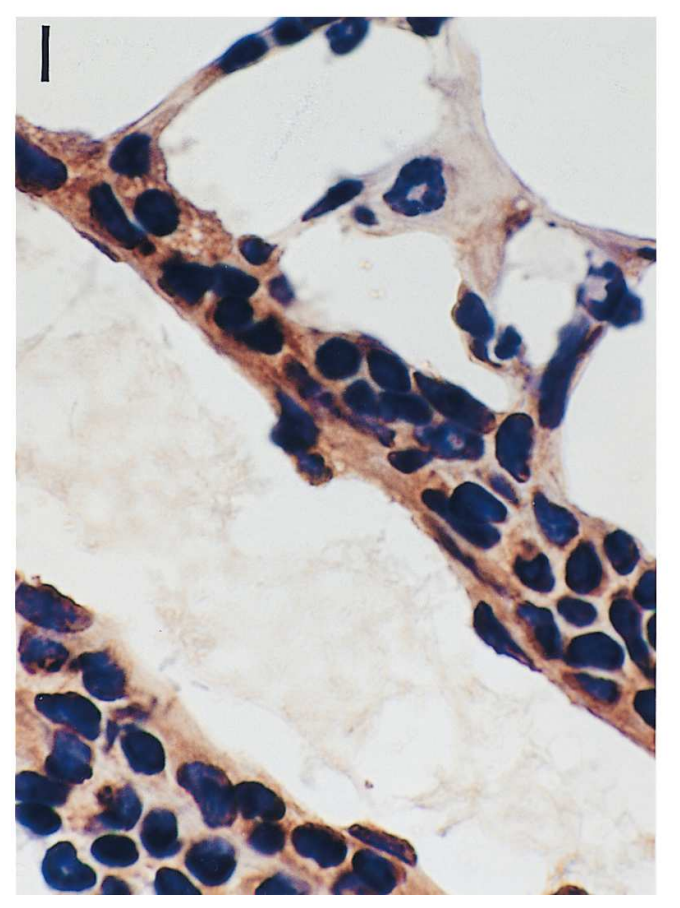

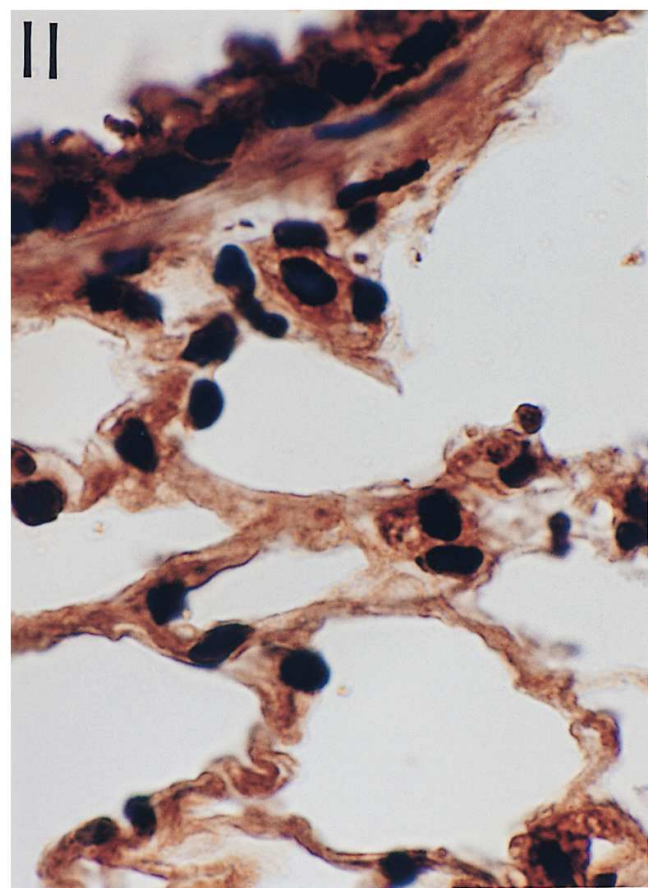

Figure 4. Role of lymphocyte subsets in lung eosinophilia and its correlation with chemokine mRNA expression. (A) OVA-induced leukocyte accumulation in the BAL fluid of lymphocytedeficient mice. BAL fluid from $\mathrm{CD} 3 \epsilon$ transgenic mice and from RAG-1, CD4-, or CD8-deficient mice was obtained $3 \mathrm{~h}$ after OVA administration on day 21 of OVA treatment. Numbers of (left) eosinophils, (middle) lymphocytes, and (right) macrophages were calculated as the product of the total cellularity of the BAL and the percentage of each cell type. Data represent the mean \pm SEM for three representative experiments with four mice in each group $(n=12)$. Numbers of infiltrating eosinophils, lymphocytes, and macrophages in the BAL fluid of two different control groups of mice (control group 1 "PBS": PBS-treated C57BL/6J or wt $129 \mathrm{sv} / \mathrm{C} 57 \mathrm{BL} / 6 \mathrm{~J}$ mice; control group 2 " +/+": OVAtreated wt $129 \mathrm{sv} / \mathrm{C} 57 \mathrm{BL} / 6 \mathrm{~J}$ mice) on day 21 is also shown. (B) Expression of the eosinophilic chemokines eotaxin, RANTES, and MIP- $1 \alpha$ mRNAs in the lung of lymphocyte-deficient mice during OVA treatment. Northern blot analysis was performed using total RNA $(20 \mu \mathrm{g})$ extracted from lungs of RAG-1, CD4-, and CD8deficient mice, $3 \mathrm{~h}$ after OVA administration on days 15,18 , and 21 . Total RNA from the lungs of OVAtreated wt mice at the same time points was used as a control. Expression of two representative wt mice out of five at each time point, two out of five immunodeficient mice on days 15 and 18 , and three out of five immunode-

ficient mice on day 21 of treatment, is shown. Expression of $\beta$-actin was used to determine the quality and quantity of the RNA. $(C)$ Expression of eotaxin protein in CD4-/- mice after OVA administration. Immunohistochemical staining was performed in frozen sections from OVA treated CD4-/ - mice (II) or OVA-treated wt littermates $(I)$ with anti-eotaxin mAb (mEOT-1). Eotaxin is clearly expressed within alveolar macrophages and alveolar epithelial cells in CD4-/- mice, although no infiltrating leukocytes were observed. $\times 1,000$

Chemokine expression during lung eosinophilia in lymphocyte deficient mice. To determine whether the absence of eosinophilia in RAG-1 and CD4-deficient mice was related to changes in the expression of eosinophilic chemokines such as eotaxin, RANTES, and MIP- $1 \alpha$, Northern analyses were performed using RNA from the lungs of these mutant mice at different time points after OVA treatment. Fig. $4 \mathrm{~B}$ shows that in RAG-1 and CD4-deficient mice, which do not develop OVA- 
Control Ab
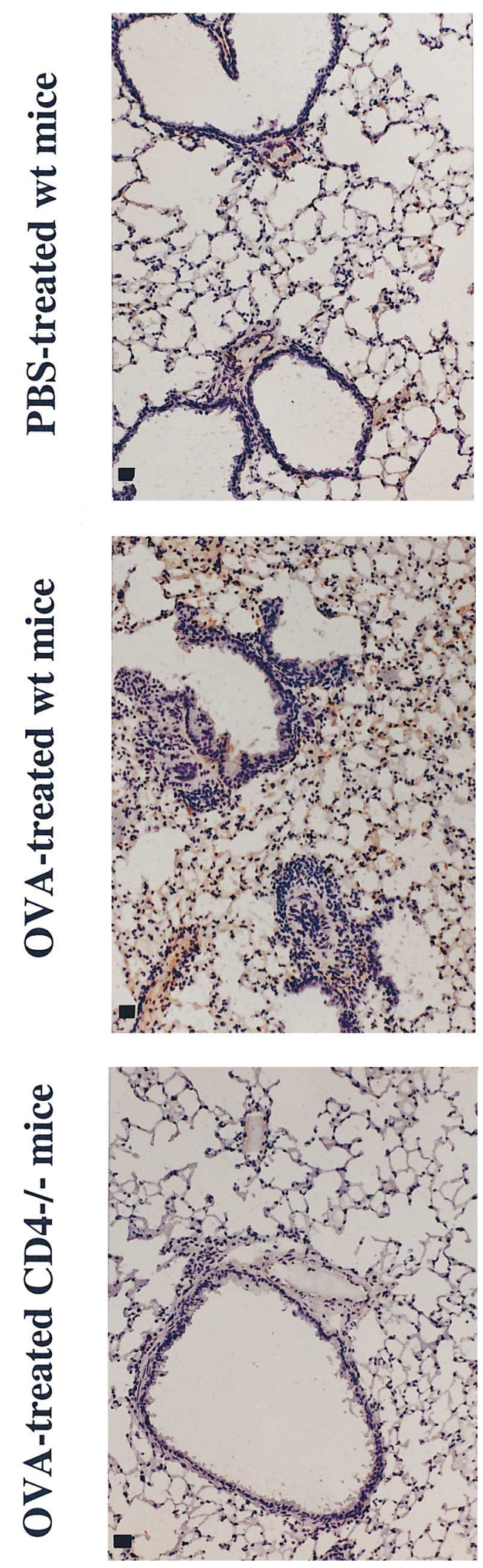

$\alpha$ ICAM-1
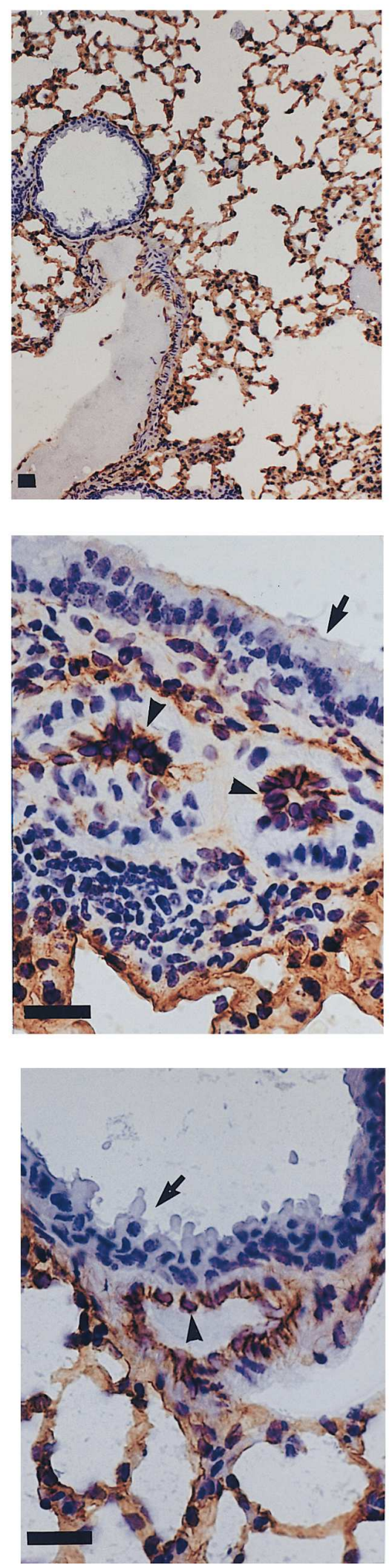

$\alpha \mathrm{VCAM}=1$
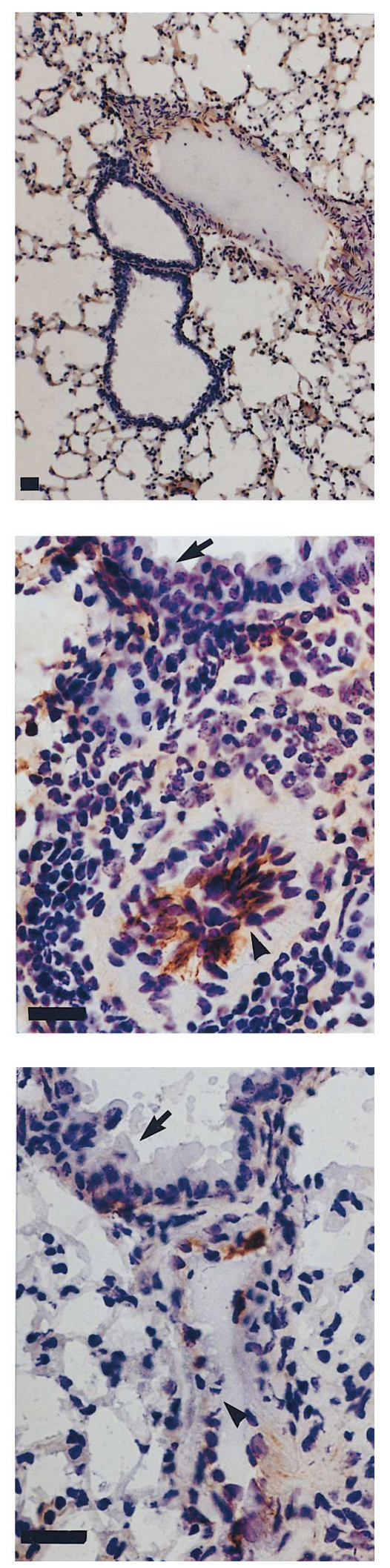

Figure 5. ICAM-1 and VCAM-1 expression in the eosinophilic lung. Frozen sections of lungs from OVA-treated wt (middle row) or CD4-deficient mice (bottom row) and of PBS-treated wt mice (top row) were stained with anti-ICAM-1 (middle column) or anti-VCAM-1 (right column) $\mathrm{mAbs}$ and then counterstained with hematoxylin. Pictures of lung sections from the same groups of mice stained with isotype-matched irrelevant control (left column) are included for comparison. Arrows indicate the position of airways and arrowheads of vessels. Bar, $50 \mu \mathrm{m}$. 

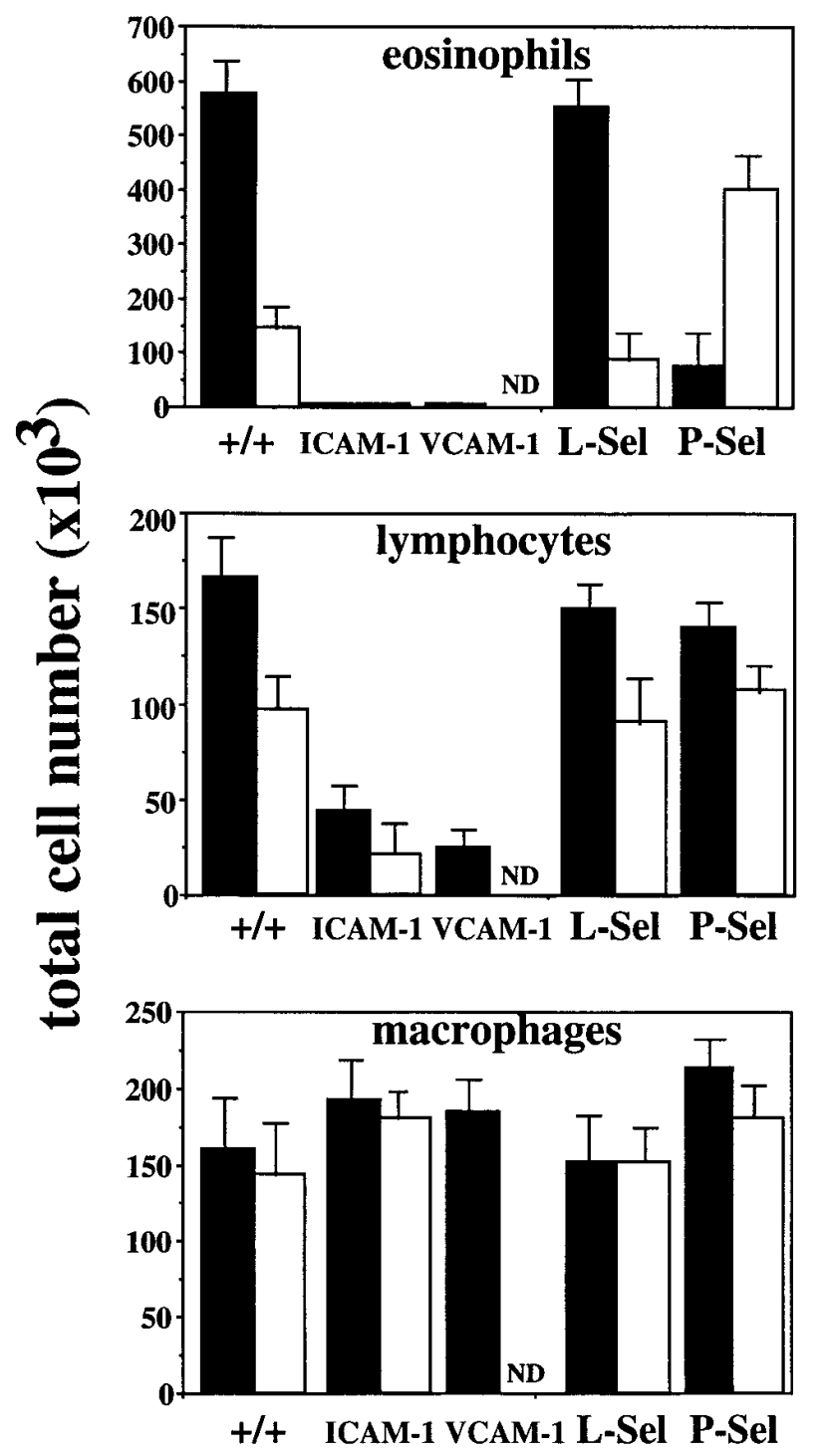

Figure 6. Enumeration of leukocytes (eosinophils, lymphocytes, and macrophages) in the BAL fluid of different adhesion receptor deficient mice in response to OVA. BAL fluid from ICAM-1, VCAM-1, L-selectin-, and P-selectin-mutant mice was obtained 3 (black bars) or $7 \mathrm{~h}$ (white bars) from different groups of mice after OVA administration on day 21 of treatment. OVA-treated wt $129 \mathrm{sv} / \mathrm{C} 57 \mathrm{BL} / 6 \mathrm{~J}$ mice were used as control $(+/+)$. Numbers of eosinophils (top), lymphocytes (middle), and macrophages (bottom) were calculated as the product of the total cellularity of the BAL and the percentage of each cell type. Figure shows mean \pm SEM for three individual experiments with 4 OVA-treated mice per time point and experiment with the exception of L-selectin-deficient mice (3 mice per time point) and VCAM-1-deficient mice. ( $N D$, not analyzed at $7 \mathrm{~h}$ after OVA treatment).

induced pulmonary eosinophilia, there was a significant level of expression of eotaxin, RANTES, and MIP-1 $\alpha$ (especially on day 21 which coincides with maximal eosinophilia in wt mice). The levels of expression of these chemokines in CD4 or RAG1-deficient mice were comparable to those found in OVAtreated wt and CD8-deficient mice (Fig. $4 \mathrm{~B}$ ). To evaluate parity between chemokine mRNA expression and chemokine protein production in the CD4-deficient mice, eotaxin protein expression was examined in sections of lungs from OVA- treated CD4-deficient mice. Even though there was no infiltration in the lungs from these mice there was at least as much, if not more, eotaxin epression within sections, correlating with the mRNA data (Fig. $4 \mathrm{C}$ ). An increase in the amount of eotaxin immunodetected on macrophages was noted (Fig. $4 \mathrm{C}$ ). Experiments are underway to confirm this finding at the molecular level.

Adhesion receptor expression during lung eosinophilia in lymphocyte-deficient mice. The mRNA expression of key eosinophilic chemokines (eotaxin and RANTES) was virtually unaffected in lymphocyte-deficient mice during the response to OVA in vivo. Therefore, we examined changes in the expression of selected adhesion receptors involved in eosinophil extravasation $(11,14)$ to determine whether suboptimal upregulation of adhesion receptor expression in lymphocyte-deficient mice could account for the lack of eosinophil accumulation observed in these mutant mice during the OVA treatment. To this end we assesed the protein expression of ICAM-1 and VCAM-1 genes by immunohistochemistry in frozen sections of the lungs of CD4-deficient mice and wt mice after OVA treatment on day 21 ( $3 \mathrm{~h}$ after challenge). Similar expression of ICAM-1 is observed in wt and CD4-deficient mice in vascular and alveolar endothelium (Fig. 5). In contrast, although strong expression of VCAM-1 was observed in wt mice after OVAtreatment (Fig. 5), it was only weakly expressed in vessels in OVA-treated CD4-deficient mice and untreated wt mice (Fig. 5). PBS-treated mice showed minimal expression of both ICAM-1 and VCAM-1 (Fig. 5).

Role of selected adhesion receptors in pulmonary eosinophilia: response to OVA in adhesion receptor deficient mice. The eosinophil-endothelial cell interactions required for extravasation necessitates enhanced expression of endothelial adhesion molecules and eosinophil surface integrins $(11,14)$. From the results presented in the previous section and from the work of others (16), we hypothesized that the expression of VCAM-1 and ICAM-1 is critically regulated by T-lymphocyte-derived cytokines and is essential for the development of lung eosinophilia. To test this hypothesis, we used ICAM-1deficient mice and VCAM-1-hypomorphic mutant mice to evaluate the specific contribution of these adhesion receptors to OVA-induced pulmonary eosinophilia. Since eosinophils express P-selectin ligands and L-selectin, mice deficient for these molecules were also used in these experiments. On day 21, $3 \mathrm{~h}$ after OVA administration, which correspond with maximum eosinophilia in wt mice, no eosinophil accumulation was observed either in the BAL fluid (Fig. 6) or in lung tissue (data not shown) of ICAM-1-deficient mice and VCAM-1-hypomorphic mutant mice. At the same time point, the total number of BAL lymphocytes in these mutant mice was reduced by more than 65 and $85 \%$ in ICAM-1 and VCAM-1-mutant mice respectively, compared to OVA-treated wt littermates (Fig. 6). Analysis of eosinophil accumulation in L-selectin-deficient mice in response to OVA showed that L-selectin is not essential for induction or maintenance of pulmonary eosinophilia. No differences in the number of BAL eosinophils were found in these mutant mice compared to control animals (Fig. 6). When numbers of BAL lymphocytes were analyzed, L-selectin-mutant mice showed an identical lymphocyte accumulation to that observed in wt littermates (Fig. 6). The BAL fluid of P-selectin-deficient mice showed only $20 \%$ of the eosinophil infiltration $3 \mathrm{~h}$ after the last OVA inhalation when compared to wt littermates (Fig. 6). Interestingly, at the same time 
point no reduction in the number of BAL lymphocytes was detected (Fig. 6). When P-selectin-deficient mice were analyzed $7 \mathrm{~h}$ after the last OVA challenge, we detected a 2.5-fold increase in the number of eosinophils in BAL fluid when compared with the OVA-treated wt mice at the same time point (Fig. 6). ICAM-1 and VCAM-1-mutant mice did not show any increase in eosinophil infiltration by $7 \mathrm{~h}$ after last OVA administration (Fig. 6). No significant differences were found in macrophage accumulation in the BAL fluid of the different mutant mice and wt littermates after challenge with OVA (Fig. 6). The lack of adhesion receptors may result in impaired eosinophil differentiation. Therefore, deficient mice were injected intravenously with IL-5. No subsequent differences in the numbers of circulating eosinophils were detected among these IL-5injected mutant and wt mice (data not shown).

\section{Discussion}

In this report we have used a mouse model of OVA-induced pulmonary eosinophilia in vivo to demonstrate that $(a)$ there is a differential accumulation of leukocyte subtypes in the lung during the response to OVA, consisting of an early accumulation of infiltrating macrophages and a late increase of T-lymphocytes and eosinophils; $(b)$ the mRNA expression of specific chemokines (eotaxin, RANTES, and MCP-1/JE) parallels infiltration of lungs by these three leukocyte subtypes; (c) neutralization of eotaxin in vivo with specific $\mathrm{Ab}$ reduces OVAinduced lung eosinophilia by $50 \% ;(d)$ mature $\mathrm{CD}^{+}{ }^{+} \mathrm{T}$ cells are absolutely required for OVA-induced eosinophil migration and accumulation in the lung; $(e)$ the presence of T cells is not required for the expression of the eosinophilic chemokines RANTES, MIP- $1 \alpha$, and eotaxin or for their proper regulation; ( $f$ ) the expression of RANTES and eotaxin is not sufficient to induce eosinophil accumulation in the absence of $\mathrm{CD} 4^{+} \mathrm{T}$ cells in vivo; $(g)$ the presence of $\mathrm{CD}^{+} \mathrm{T}$ cells is critical for the proper enhancement of VCAM-1, but not ICAM-1 expression, in the lung during OVA treatment; and $(h)$ the absence of ICAM-1 or VCAM-1 prevents the development of pulmonary eosinophilia whereas expression of L-selectin and P-selectin is not essential to achieve lung eosinophil accumulation in vivo.

The accumulation of eosinophils and T-lymphocytes in the lung is parallel, and is preceded by a transient accumulation of macrophages. This differential accumulation correlates with a distinct pattern of expression of specific chemokines. The recruitment of leukocytes from the blood to sites of inflammation is strongly regulated in vivo by mechanisms that allow selective leukocyte-endothelial cell recognition. These mechanisms display total specificity in relation to the stimulus inducing inflammation, cell response, and the tissue site involved. Based on a murine model of lung eosinophilia induced by the repeated exposure of mice to aerosolized OVA (23), we have analyzed cell subtypes involved in eosinophilia. We describe here that there is a macrophage accumulation at the early stages of challenge and that T-lymphocytes parallel eosinophil infiltration. Whereas eosinophils and T-lymphocytes were predominant on day 21 in both BAL and lung tissue, macrophages were the most abundant leukocyte type on day 15 in the lungs of OVA-treated mice (Fig. 1). These two events characterize pulmonary eosinophilia in this model. No significant and ordered neutrophil or B cell accumulation was detected during the course of OVA treatment (data not shown). Mast cells, which have been described as participating in eosinophil-mediated inflammatory reactions (69), are not significantly increased during the development of this model of antigen-induced eosinophilia (data not shown).

The presence of infiltrating macrophages in the lung during the sensitization phase (day 8; data not shown) and early stage of OVA challenge (Fig. 1) is consistent with the hypothesis that these leukocytes play a prominent role in airway hyperresponsiveness $(8,27)$. To dissect the specific role that macrophages might play in this model of OVA-induced eosinophilia, we attempted to eliminate macrophages in vivo using the drug dichloromethylene-diphosphonate $\left(\mathrm{Cl}_{2} \mathrm{MDP}\right)$ encapsulated in liposomes (70). Although a clear reduction $(60 \%)$ in BAL pulmonary eosinophilia was detected in $\mathrm{Cl}_{2} \mathrm{MDP}$-treated mice after OVA-challenge, these experiments were unsatisfactory due to the incomplete depletion of macrophages and to possible secondary effects of the drug (data not shown). The study of the role of macrophages in lung eosinophilia using a genetically "clean" system is hampered by the lack of availability of macrophage deficient mice. Mice lacking M-CSF (op/op) or GM-CSF expression or both, still have significant numbers of alveolar macrophages $(71,72)$. Thus, although our preliminary results suggest a participation of macrophages in the early phases of lung eosinophilia, the final confirmation of these results awaits the development of better tools (macrophage-deficient mice) to address this issue.

Interestingly, we found that MCP-1/JE expression correlates with lung macrophage accumulation whereas the expression of RANTES and eotaxin is concomittant with lymphocyte and eosinophil infiltration (Fig. $2 A$ ). The expression pattern of MIP- $1 \alpha$ mRNA reflects that seen for eotaxin and RANTES rather than the mRNA pattern observed for MCP-1/JE (Fig. 2 $A$ ). This result suggests that MIP- $1 \alpha$ is playing a role in the recruitment of eosinophils in our model and is in accordance with the recent description of MIP- $1 \alpha$ as an eosinophilic chemokine (65). Taken together these findings indicate that there is a differential expression of chemokines during OVAinduced eosinophilia in vivo which directly correlates with the arrival of specific leukocyte types in the lung.

Of the chemokines able to attract eosinophils, eotaxin appears to be one of the most efficient $(20,67)$. This has led us and others to suggest that this chemokine might play a key role in lung allergic eosinophilia. In fact, neutralization of eotaxin at day 21 in our model demonstrated that this chemokine is responsible for the recruitment of approximately half of the eosinophils that accumulate in the BAL fluid in response to allergen challenge (Fig. 3). We are presently evaluating further the specific contribution of eotaxin at different times of this allergic response in the lung, as well as its overall contribution to this process. Our results indicate that most of the infiltrating leukocytes (eosinophils, lymphocytes, and monocytes) are not producing eotaxin protein, at least at the time of maximal eosinophilia (day 21, $3 \mathrm{~h}$ after OVA inhalation). We have previously reported that lymphocytes and monocytes can produce eotaxin mRNA after activation in vitro (23). Similarly, Ponath et al. reported that human eosinophils are able to produce eotaxin mRNA (67). However, at the point of maximal eosinophilia in vivo, these three cell types do not overtly produce eotaxin protein. Rather, the principal cells producing eotaxin in response to OVA in this model are resident lung cells (mainly epithelial cells and alveolar macrophages with some possible contribution from endothelial cells). 
The presence of $\mathrm{CD}^{+} \mathrm{T}$ cells is essential for the development of lung eosinophilia in vivo, but not for the expression of eosinophilic chemokines. To evaluate the relevance of lymphocytes and of specific subpopulations in OVA-induced eosinophil accumulation in the lung and the putative role that these cells might play, we have used mice lacking specific lymphocyte subtypes. Here we demonstrate that there is no OVAinduced eosinophil accumulation in the BAL fluid of RAG-1deficient mice (lacking T- and B-lymphocytes) (68) or CD3€ transgenic mice (lacking $\mathrm{T}$ and NK cells) (48) (Fig. $4 A$ ). This suggests that $\mathrm{T}$ cells are required for the induction of lung eosinophilia and that B cells are not sufficient to induce this physiological response. Since we did not detect any significant lymphocyte infiltration in CD $3 \epsilon$ transgenic mice, the OVA-induced lymphocyte infiltrate must be composed predominantly of T cells (Fig. $4 A$ ). This was confirmed by stained lung sections from OVA-treated mice with an anti-IgM mAb (data not shown). Furthermore, the prevention of eosinophil accumulation in BAL and lung tissue in $\mathrm{CD}^{+} \mathrm{T}$-lymphocyte-deficient, but not in $\mathrm{CD}^{+}$T-lymphocyte-deficient mice after OVAchallenge (Figs. 4, 5, and data not shown) demonstrates that $\mathrm{CD} 4^{+} \mathrm{T}$-lymphocytes are required for the induction and development of lung eosinophilia.

A number of studies have showed that airway hyperresponsiveness and pulmonary inflammation can be associated with a Th2 pattern of cytokine expression (37, 73-76). As yet, there has been no direct evidence that T-lymphocytes mediate in vivo antigen-induced eosinophilia. As demonstrated using SCID mice, airway hyperreactivity induction requires the presence of lymphocytes (75) but the association of airway hyperreactivity and pulmonary eosinophil infiltration is still not understood since neither IL-5 or eosinophils support airway hyperreactivity in an in vivo murine model of pulmonary inflammation (75). Elegant and thorough studies have demonstrated a key role for $\mathrm{CD} 4^{+} \mathrm{T}$ cells in the development of tracheal (77) or pulmonary (78) antigen-induced eosinophil infiltration by mAb-depletion of $\mathrm{CD}^{+} \mathrm{T}$ cells. However, a critical role for $\mathrm{CD}^{+} \mathrm{T}$ cells in the development of lung eosinophilia and airway responsiveness has also been documented in another model of airway sensitization in which priming by intraperitoneal injection of OVA was omitted (79). Expression of chemokines during $\mathrm{CD}^{+}{ }^{+}$or $\mathrm{CD}^{+} \mathrm{T}$ cell-dependent eosinophilia in these two different mouse models is currently being investigated in our laboratory. These results illustrate that the contribution of $\mathrm{CD}^{+}{ }^{+}$or $\mathrm{CD}^{+} \mathrm{T}$ cells to eosinophil accumulation is dependent upon the particular methods used to induce allergic inflammation. In addition, the results obtained from all these experiments are conditioned by the finding that human eosinophils also express the CD4 receptor (14) and by possible secondary effects mediated by the injection of mAbs in vivo. In this study we use a "clean" genetic deficiency to demonstrate that the absence of $\mathrm{CD}^{+}{ }^{+} \mathrm{T}$-lymphocytes (but not $\mathrm{CD} 8^{+}$ $\mathrm{T}$ cells) abolishes pulmonary eosinophilia without affecting eosinophil differentiation. On the other hand, in these immunodeficient mice it is difficult to decide whether the interference with the sensitization and/or with the induction phase of the response to OVA results in the lack of eosinophil infiltration. We are evaluating the OVA-induced immune response in lymphocyte-deficient mice as well as establishing the role that $\mathrm{B}$ and $T$ cells play in both the sensitization and challenge phases by depletion of these particular lymphocyte subtypes at different time points of the treatment. This will lead us to a better characterization of both the sensitization and induction phases of the response in our murine model of lung eosinophilia. Another possible explanation for the absence of eosinophilia in CD4-deficient mice could be a decrease in the number of bone marrow or peripheral blood eosinophils because of the CD4 deficiency. CD4-deficient mice and wt littermates were found to have similar basal levels of eosinophils in peripheral blood before treatment (data not shown). After OVA treatment, it is possible that levels of peripheral blood eosinophils are lower in CD4-deficient mice. We could not test this hypothesis directly by evaluating increases in peripheral blood eosinophils in OVA-treated CD4-deficient mice because no such increase is detected after treatment of wt mice in this model. Instead, we took advantage of the fact that intravenous IL-5 induces a rapid reduction in the number of eosinophils in bone marrow due to their mobilization to the blood (43). We did not detect any differences in the number of IL-5-mobilized circulating eosinophils among these wt and mutant mice (not shown). In addition, eosinophil accumulation in the peritoneum of CD4deficient mice after repeated peritoneal administration of IL-5 suggests that these leukocytes maintain their ability to extravasate in vivo, at least to the peritoneum.

We hypothesized that $\mathrm{CD} 4^{+}$lymphocytes might be essential for the development of lung eosinophilia because they produce or regulate the expression of eosinophilic chemokines or because they regulate the upregulation/activation of critical adhesion receptors used by eosinophils during their transmigration in vivo. As shown above, the infiltrating cells in the lung are not the main producers of at least one eosinophilic chemokine, eotaxin (Fig. 2 B). Therefore, we would not expect a reduction of eotaxin or RANTES expression in CD4-deficient mice. However, $\mathrm{CD} 4^{+} \mathrm{T}$-lymphocytes can provide signals that regulate the expression of these chemokines by epithelial and endothelial cells. To test these possibilities, we studied the RNA expression of eotaxin and RANTES in lymphocyte-deficient mice.

The mRNA expression of chemokines able to induce eosinophil recruitment (eotaxin, RANTES, and MIP-1 $\alpha$ ) after OVA administration, is not influenced in lymphocyte-deficient mice. In RAG-1 and CD4-deficient mice, that are resistant to OVA-induced pulmonary eosinophilia, there exist significant levels of eotaxin, RANTES, and MIP-1 $\alpha$ expression when compared with OVA-treated wt and CD8-deficient mice. This finding was subsequently confirmed at the protein level for eotaxin. Based on these results, we can conclude that the expression of these chemokines alone is not sufficient to drive leukocyte recruitment in vivo and, that $\mathrm{CD}^{+} \mathrm{T}$ cells, which are absolutely required for induction of eosinophilia, do not regulate the expression of these eosinophilic chemokines. Possible candidates capable of regulating the expression of chemokines in the lung of lymphocyte-deficient mice could be mast cells or macrophages. On the other hand, the expression of these eosinophilic chemokines in RAG-1-deficient mice or CD4-deficient mice is not due to a non-specific response to large doses of OVA or to the effect of some contaminant since we have recently reported that the novel eosinophilic chemokine MCP-5 (80) is expressed in the lung of wt mice but not of RAG-1deficient mice after OVA treatment (80).

The expression of selected adhesion molecules is T-lymphocyte dependent. The expression of ICAM-1 and VCAM-1 is critical for the accumulation in vivo of eosinophils in the lung. The process of eosinophil-endothelial cell interactions 
involves several adherence pathways (14). Eosinophils can bind to ICAM-1 and to VCAM-1 by means of LFA-1 and VLA-4, respectively. They also express L-selectin and ligands for P-selectin $(11,12)$. We examined the expression of both ICAM-1 and VCAM-1 proteins in our model of OVA-induced eosinophilia in wt and CD4-deficient mice. While OVAtreated wt and CD4-deficient mice exhibited similar staining patterns of ICAM-1 protein expression in alveoli and blood vessels (Fig. 5) a differential staining pattern was clearly observed for VCAM-1, where increased vascular endothelial staining was detected in OVA-treated wt, but not in CD4-deficient mice (Fig. 5). This implies that adhesion molecules are differentially modulated by $\mathrm{CD} 4^{+} \mathrm{T}$ cells since we have shown that VCAM-1, but not ICAM-1, is dramatically increased in the presence, but not absence, of these cells, and that $\mathrm{CD}^{+} \mathrm{T}$ cells are not directly involved in the regulation of ICAM-1 protein expression.

We have examined the role that the adhesion receptors ICAM-1, VCAM-1, P-selectin, and L-selectin play in OVAinduced pulmonary eosinophilia by using mice lacking these adhesion molecules. Our studies in vivo demonstrate that eosinophil migration into the lung tissue (data not shown) and BAL fluid (Fig. 6) is abolished in the absence of ICAM-1 and VCAM-1. Previous in vivo blocking experiments have shown that VCAM-1/VLA-4 interactions play a predominant role in controlling antigen-induced eosinophil and $\mathrm{T}$ cell recruitment into the mouse trachea but ICAM-1/LFA-1 interactions are only critical in regulating $\mathrm{T}$ cell recruitment in the same model of inflammation (16). Studies of eosinophil transmigration in vitro have reported a $24 \%$ reduction in IL- 1 or TNF- $\alpha$-induced eosinophil migration by using $\mathrm{mAb}$ against ICAM-1 while the combination of anti-E-selectin, anti-VCAM-1, and antiICAM-1 mAbs resulted in additive inhibition of transmigration (15). Our results indicate that OVA-induced eosinophil accumulation in the lung requires interactions mediated by ICAM-1 and VCAM-1 with their counter-receptors. In both strains of adhesion receptor-deficient mice, no eosinophils were detected in BAL fluid after OVA treatment (Fig. 6). Furthermore, $\mathrm{T}$ cell infiltration is also affected in ICAM-1 and VCAM-1-mutant mice. We found a 32 and 14\% lymphocyte accumulation in the BAL fluid of OVA-treated ICAM-1-deficient mice and VCAM-1-hypomorphic mutant mice, respectively, when compared with OVA-treated wt controls (Fig. 6). Since CD $4^{+}$T-lymphocytes are essential for the development of pulmonary eosinophilia during OVA treatment, we can not conclude from these experiments whether ICAM-1 and/or VCAM-1 play a critical role in lung eosinophilia either by directly mediating eosinophil-endothelium interactions or by facilitating $\mathrm{CD}^{+}{ }^{+} \mathrm{T}$ cell activation and/or infiltration, or both effects together. Adoptive transfer experiments into deficient mice are underway in our laboratory to address this question.

In contrast, the absence of L-selectin and P-selectin expression does not prevent the development of pulmonary eosinophilia in this model. The number of BAL leukocyte subtypes remained comparable in L-selectin-deficient mice and wt littermates at the different time points analyzed ( 3 and $7 \mathrm{~h}$ ) after OVA administration on day 21 (Fig. 6). Three hours after OVA challenge on the same day, P-selectin-deficient mice have fewer eosinophils in the lung than wt mice. BAL fluid obtained from these treated mice showed $20 \%$ of the eosinophil accumulation observed in wt littermates without reduction in the number of infiltrating lymphocytes (Fig. 6). Since lympho- cyte migration remains unaffected, the reduced eosinophilia at this time point might be directly attributable to the effect of the P-selectin deficiency. However, the increase in the number of eosinophils (2.5-fold over the control at this time point) in the BAL fluid of OVA-treated P-selectin-deficient mice obtained $7 \mathrm{~h}$ after OVA challenge, suggests that in the absence of P-selectin-mediated interactions, eosinophil accumulation in the lung is suboptimal and therefore delayed in vivo. However, $\mathrm{P}$-selectin is not essential for the development of eosinophilia since in the absence of P-selectin expression, eosinophils and endothelial cells use alternative adhesion pathways that allow delayed eosinophil migration into the lung.

Numbers of macrophages (Fig. 6) and neutrophils (data not shown) present in the BAL fluid of OVA-treated mutant mice were also similar when compared with wt animals (data not shown). The only exception was a $40 \%$ reduction in neutrophils in ICAM-1-deficient mice (not shown). This reduction was also detectable in these mutant mice even before treatment and may be related to the fact that ICAM- 1 is required for neutrophils to migrate into tissues (52).

The study of leukocytes and the molecules that they produce or upregulate during recruitment and accumulation of specific leukocyte subsets into sites of inflammation, may lead to the development of therapeutic approaches able to inhibit the pathogenesis of allergic inflammation. Asthma is a complex syndrome that involves recruitment of eosinophils and their accumulation in the lung. Although murine models of lung inflammation do not completely represent the complexity of this syndrome, they may delineate particular pathways operating within it. The results presented here using one particular murine model together with additional information yielded from other, different, models of lung inflammation may contribute to a better comprehension of the mechanisms implicated in the establishment of eosinophilia within the inflammatory lung.

\section{Acknowledgments}

The authors are indebted to Drs. C. Mackay, C. Gerard, and B. Rollins for critical reading of this manuscript; to Drs. M. Dorf, T. Schall, and B. Rollins for providing MIP- $1 \alpha$, RANTES, and MCP-1/JE probes, respectively; to Drs. Tak W. Mak, Laura Martin (AMGEN Institute), and C. Terhorst (Beth Israel Hospital, Boston, MA) for their help in providing CD4- and CD8-deficient mice and CD3€ transgenic mice, respectively; to Dr. L. Kobzic for advice on lung histology; Dr. M. Soares for her helpful discussions; and to C. Gomez Mouton and M. Catalina for their skillful work.

This work has been funded by National Institutes of Health grants HL 148675-02, CiCyT PB93-0317, HL94-10-B, HL36028 and the Aplastic Foundation of America. J-A. Gonzalo is a recipient of postdoctoral fellowship from the Spanish Ministry for Science. M. Cybulski is an established investigator of the American Heart Association. J-C. Gutierrez-Ramos is the Amy C. Potter fellow.

\section{References}

1. Spry, C.J. 1971. Mechanism of eosinophilia. Cell Tissue Kinet. 4:351-364. 2. De Monchy, J.G.R., H.F. Kauffman, P. Venge, G.H. Koeter, H.M. Jansen, H.J. Sluiter, and K. de Vries. 1985. Bronchoalveolar eosinophilia during allergen-induced late asthmatic reactions. Am. Rev. Respir. Dis. 131:373-380.

3. Gleich, G. 1990. The eosinophilic and bronchial asthma. Current understanding. J. Allergy Clin. Immunol. 85:422-436.

4. Lamas, A.C., C.M. Mulroney, and R.P. Schleimer. 1988. Studies on the adhesive interaction between purified human eosinophils and cultured vascular endothelial cells. J. Immunol. 140:1500-1505.

5. Walsh, G.M., A. Hartnell, A.J. Wardlaw, K. Kurihara, C.J. Sanderson, 
and A.B. Kay. 1990. IL-5 enhances the in vitro adhesion of human eosinophils, but not neutrophils, in a leucocyte integrin (CD11/18)-dependent manner. Int. Arch. Allergy Appl. Immunol. 94:174-178.

6. Butcher, E.C. 1991. Leukocyte-endothelial cell recognition: three (or more) steps to specificity and diversity. Cell. 67:1033-1036.

7. Lasky, L.A. 1992. Selectins: interpreters of cell-specific carbohydrate information during inflammation. Science (Wash. DC). 258:964-969.

8. Drazen, J.M., J.P. Arm, and K.F. Austen. 1996. Sorting out the cytokines of asthma. J. Exp. Med. 183:1-5.

9. Springer, T.A. 1994. Traffic signals for lymphocyte recirculation and leukocyte emigration: the multistep paradigm. Cell. 76:301-314.

10. Schweighoffer, T., and S. Shaw. 1992. Adhesion cascades: diversity through combinatorial strategies. Curr. Opin. Cell Biol. 4:824-831.

11. Resnick, M.B., and P.F. Weller. 1993. Mechanisms of eosinophil recruitment. Am. J. Respir. Cell. Mol. Biol. 8:349-355.

12. Lewinsohn, D.M., R.F. Bargatze, and E.C. Butcher. 1987. Leukocyteendothelial cell recognition: evidence of a common molecular mechanism shared by neutrophils, lymphocytes and other leukocytes. J. Immunol. 138: 4313-4319.

13. Walsh, G.M., J.J. Mermod, A. Hartnell, A.B. Kay, and A.J. Wardlaw. 1991. Human eosinophil, but not neutrophil, adherence to IL-1-stimulated human umbilical vascular endothelial cells is a4b1 (very late antigen-4) dependent. J. Immunol. 146:3419-3426.

14. Weller, P.F., T.H. Rand, S.E. Goelz, G. Chi-Rosso, and R.J. Lobb. 1991. Human eosinophil adherence to vascular endothelium mediated by binding to VCAM-1 and ELAM-1. Proc. Natl. Acad. Sci. USA. 88:7430-7433.

15. Ebisawa, M., B.S. Bochner, S.N. Georas, and R.P. Schleimer. 1992. Eosinophil transendothelial migration induced by cytokines. I. Role of endothelial and eosinophil adhesion molecules in IL-1b-induced transendothelial migration. J. Immunol. 149:4021-4028.

16. Nakajima, H., H. Sano, T. Nishimura, S. Yoshida, and I. Iwamoto. 1994. Role of vacular cell adhesion 1/very late antivation antigen 4 and intercellular adhesion molecule 1/lymphocyte function-associated antigen 1 interactions in antigen-induced eosinophil and T cell recruitment into the tissue. J. Exp. Med. 179:1145-1154.

17. Wegner, C., R. Gundel, P. Reily, N. Haynes, L. Letts, and R. Rothlein. 1990. Intercellular adhesion molecule-1 (ICAM-1) in the pathogenesis of asthma. Science (Wash. DC). 247:456-459.

18. Dahinden, C.A., T. Geiser, T. Brunner, V. von Tscharner, D. Caput, P. Ferrara, A. Minty, and M. Baggiolini. 1994. Monocyte chemotactic protein 3 is most effective basophil- and eosinophil-activating chemokine. J. Exp. Med. 179: 751-756

19. Rot, A., M. Krieger, T. Brunner, S.C. Bischoff, T.J. Schall, and C.A. Dahinden. 1992. RANTES and macrophage inflammatory protein 1 alpha induce the migration and activation of normal human eosinophil granulocytes. J. Exp. Med. 176:1489-1495.

20. Jose, P.J., D.A. Griffiths-Johnson, P.D. Collins, D.T. Walsh, R. Moqbel, N.F. Totty, O. Truong, J.J. Hsuan, and T.J. Williams. 1994. Eotaxin: a potent eosinophil chemoattractant cytokine detected in a guinea pig model of allergic airways inflammation. J. Exp. Med. 179:881-887.

21. Rothenberg, M.E., A.D. Luster, C.M. Lilly, J.M. Drazen, and P. Leder. 1995. Constitutive and allergen-induced expression of eotaxin mRNA in the guinea pig lung. J. Exp. Med. 181:1211-1216.

22. Rothenberg, M.E., A.D. Luster, and P. Leder. 1995. Murine eotaxin: an eosinophil chemoattractant inducible in endothelial cells and in interleukin 4-induced tumor suppression. Proc. Natl. Acad. Sci. USA. 92:8960-8964.

23. Gonzalo, J.A., G.-Q. Jia, V. Aguirre, D. Friend, A.J. Coyle, N.A. Jenkins, G.S. Lin, H. Katz, A. Litchman, N. Copeland, et al. 1996. Mouse eotaxin expression parallels eosinophil accumulation during lung allergic inflammation but it is not restricted to a Th2-type response. Immunity. 4:1-14.

24. Ponath, P.D., S. Qin, D.J. Ringler, I. Clark-Lewis, J. Wang, N. Kassam, H. Smith, X. Shi, J.-A. Gonzalo, W. Newman, et al. 1996. Cloning of the human eosinophil chemoattractant, eotaxin. J. Clin. Invest. 97:604-612.

25. Fels, A.O.S., N.A. Pawlowski, and E.B. Cramer. 1982. Human alveolar macrophages produce leukotriene B4. Proc. Natl. Acad. Sci. USA. 79:78667870 .

26. Chervenick, P.A., and A.F. LoBuglio. 1972. Human blood monocytes: stimulators of granulocyte and mononuclear colony formation in vitro. Science (Wash. DC). 178:164-169.

27. Elias, J.A., A.D. Schreiber, and K. Gostilo. 1985. Differential interleukin-1 elaboration by unfractionated and density fractionated human alveolar macrophages and blood monocytes. J. Immunol. 135:3198-3204.

28. Lopez, A.F., D.J. Williamsom, and J.R. Gamble. 1986. Recombinant human granulocyte-macrophage colony-stimulating factor stimulates in vitro mature human neutrophil and eosinophil function, surface receptor expression and survival. J. Clin. Invest. 78:1220-1228.

29. Bradley, B.L., M. Azzawi, M. Jacobson, B. Assoufi, J.V. Collins, A.-M.A. Irani, L.B. Schwartz, S.R. Durham, P.K. Jeffrey, and A.B. Kay. 1991. Eosinophils, T-lymphocytes, mast cells, neutrophils and macrophages in bronchial biopsy specimens from atopic subjects with asthma: comparison with biopsy specimens from atopic subjects without asthma and normal control subjects and relationship to bronchial hyperresponsiveness. J. Allergy Clin. Immunol. 88:
661

30. Bentley, A.M., P. Maestrelli, M. Saetta, L.M. Fabbri, D.S. Robinson, B.L. Bradley, P.K. Jeffery, S.R. Durham, and A.B. Kay. 1992. Activated-T lymphocytes and eosinophils in the bronchial mucosa in isocyanate-induced asthma. J. Allergy Clin. Immunol. 89:821-829.

31. Frew, A.J., and A.B. Kay. 1990. Eosinophils and T-lymphocytes in late phase allergic reactions. J. Allergy Clin. Immunol. 85:422-429.

32. Walker, C., J.C. Virchow, P.L.B. Bruijnzeel, and K. Blaser. 1991. T cell subsets and their soluble products regulate eosinophilia in allergic and non-allergic asthma. J. Immunol. 146:1829-1835.

33. Sanderson, C.J. 1992. Interleukin-5, eosinophils and disease. Blood. 79: 3101-3109.

34. Bousquet, J., P. Chanwz, J.Y. Lacoste, G. Barneon, N. Ghavaman, I. Enander, P. Venge, S. Ahlstedt, J. Simony-Lafountaine, P. Godard, and P.-B. Michel. 1990. Eosinophilic inflammation in asthma. N. Engl. J. Med. 323:10331039.

35. Basten, A., and P.B. Beeson. 1970. Mechanism of eosinophilia. II. Role of the lymphocytes. J. Exp. Med. 131:1288-1294.

36. Sanderson, C.J., D.J. Warren, and M. Strath. 1985. Identification of a lymphokine that stimulates eosinophil differentiation in vitro. J. Exp. Med. 162 60-69.

37. Robinson, D.S., Q. Hamid, S. Ying, A. Tsicopoulus, J. Barkans, A.M. Bentley, C. Corrigan, S.R. Durham, and A.B. Kay. 1992. Predominant Th2-like bronchoalveolar T-lymphocyte population in atopic asthma. N. Engl. J. Med. 326:298-303.

38. Del Prete, G.F., E. Maggi, P. Parronchi, I. Chretien, A. Jiri, D. Macchia, M. Ricci, J. Banchereau, J. De Vries, and S. Romagnani. 1988. IL-4 is an essential factor for the $\operatorname{IgE}$ synthesis induced in vitro by human $\mathrm{T}$ cell clones and their supernatants. J. Immunol. 140:4193-4199.

39. Briscoe, D.M., R.S. Cotran, and J.S. Pober. 1992. Effects of tumor necrosis factor, lipopolysaccharide and IL-4 on the expression of vascular cell adhesion molecule-1 in vivo. J. Immunol. 149:2954-2961.

40. Schleimer, R.P., S.A. Sterbinsky, J. Kaiser, C.A. Bickel, D.A. Klunk, and K. Tomioka. 1992. IL-4 induces adherence of human eosinophils and basophils but not neutrophils to endothelium. Association with expression of VCAM-1. J. Immunol. 148:1086-1092.

41. Pober, J.S., M.A. Gimbrone, L.A. Lapierre, D.L. Mendrick, W. Fiers, R Rothlein, and T.A. Springer. 1986. Overlapping patterns of activation of human endothelial cells by interlekin-1, tumor necrosis factor and immune interferon. J. Immunol. 137:1893-1896.

42. Schall, T.J., J. Jongstra, B.J. Dyer, J. Jorgensen, C. Clayberger, M.M. Davis, and A.L. Krensky. 1989. A human T cell-specific molecule is a member of a new gene family. J. Immunol. 141:1018-1025.

43. Collins, P.D., S. Marleau, D.A. Griffiths-Johnson, P.J. Jose, and T.J. Williams. 1995. Cooperation between interleukin-5 and the chemokine eotaxin to induce eosinophil accumulation in vivo. J. Exp. Med. 182:1169-1174.

44. Carlos, T.M., and J.M. Harlan. 1994. Leukocyte-endothelial adhesion molecules. Blood. 84:2068-2101.

45. Ley, K. 1996. Gene-targeted mice in leukocyte adhesion research. Microcirculation. In press.

46. Rahemtulla, A., W.P. Fung-Leung, M.W. Schiham, T.M. Kundig, S. Sambhara, A. Narendran, A. Arabian, A. Wakeham, C. Paige, J., R.M. Zinkernagel, et al. 1991. Normal development and function of $\mathrm{CD}^{+}$cells but markedly decreased helper cell activity in mice lacking CD4. Nature (Lond.). 353: 180-184.

47. Fung-Leung, W.-P., M.W. Schilham, A. Rahemtulla, T.M. Kundig, M. Vollenweider, J. Potter, W. van Ewijk, and T.W. Mak. 1991. CD8 is needed for development of cytotoxic T cells but not helper T cells. Cell. 65:443-449.

48. Wang, B., C. Biron, J. She, J. Sancho, L.C.P., K. Higgins, M. Sunshine, E. Lacy, N. Lonberg, and C. Terhorst. 1994. High level expression of the cytoplasmic tail of CD3- $\epsilon$ in transgenic mice blocks both early T-lymphocytes and natural killer cell development. Proc. Natl. Acad. Sci. USA. 91:9402-9406.

49. Gurtner, G.C., V. Davis, H. Li, M.J. McCoy, A. Sharpe, and M.I. Cybulsky. 1995. Targeted disruption of the murine VCAM1 gene: essential role of VCAM-1 in chorioallantoic fusion and placentation. Genes Dev. 9:1-14.

50. Li, H., M. Iiyama, M. DiChiara, G.C. Gurtner, D.S. Milstone, and M.I. Cybulsky. 1996. A Hypomorphic VCAM-1 Mutation Rescues the Embryonic Lethal Null Phenotype and Reveals a Requirement for VCAM-1 in Inflammation. FASEB J. In press.

51. Chuluyan, H.E., L. Osborn, R. Lobb, and A.C. Issekutz. 1995. Domains 1 and 4 of vascular cell adhesion molecule-1 (CD106) both support very late activation antigen-4 (CD49d/CD29)-dependent monocyte transendothelial migration. J. Immunol. 155:3135-3143.

52. Xu, H., J.A. Gonzalo, Y. St. Pierre, I.R. Williams, T.S. Kupper, R.S Cotran, T.A. Springer, and J.-C. Gutierrez-Ramos. 1994. Leukocytosis and resistance to septic shock in intercellular adhesion molecule 1 -deficient mice. $J$. Exp. Med. 180:95-109.

53. Chomczynski, P., and N. Sacchi. 1987. Single-step method of RNA isolation by acid guanidinium thiocyanate-phenol-chloroform extraction. Anal. Biochem. 162:156-159.

54. Sambrook, J., Fritsch, E.F., and Maniatis, T. 1989. Molecular Cloning: A Laboratory Manual. 2nd Ed. Cold Spring Harbor Laboratory Press, Cold 
Spring Harbor, NY.

55. Heeger, P., G. Wolf, C. Meyers, M.J. Sun, S.C. O'Farrell, A.M. Krensky, and E.G., Neilson. 1992. Isolation and characterization of cDNA from renal tubular epithelium encoding murine RANTES. Kidney Int. 41:220-226.

56. Rollins, B.J., E.D. Morrison, and C.D. Stiles. 1988. Cloning and expression of JE, a gene inducible by platelet-derived growth factor and whose product has cytokine -like properties. Proc. Natl. Acad. Sci. USA. 85:3738-3742.

57. Widmer, U., V.D. Yang, K.R. Manogue, B. Sherry, and A. Cerami. 1991. Genomic structure of murine macrophage inflammatory protein-1 $\alpha$ and conservation of potential regulatory sequences with a human homolog, $\mathrm{LD} 78^{1.2}$. J. Immunol. 146:4031-4040.

58. Burd, P.R., G.J. Freeman, S.D. Wilson, M. Berman, R. DeKruyff, P.R. Billings, and M.E. Dorf. 1987. Cloning and characterization of a novel T cell activation gene. J. Immunol. 139:3126-3132.

59. Harlow, E., and D. Lane. 1988. Antibodies: A Laboratory Manual. Cold Spring Harbor Press, Cold Spring Harbor, NY.

60. Lin, G., E. Finger, and J.C. Gutierrez-Ramos. 1995. Expression of CD34 in endothelial cells, hematopoietic progenitors and nervous cells in fetal and adult mouse tissues. Eur. J. Immunol. 25:1508-1516.

61. Van Vliet, E., M. Melis, and W. Van Ewijk. 1984. Monoclonal Antibodies to stromal cell types of the mouse thymus. Eur. J. Immunol. 14:524-529.

62. Schall, T.J., K. Bacon, K.I. Toy, and D.V. Goeddel. 1990. Selective attraction of monocytes and T lymphocytes of the memory phenotype by cytokine RANTES. Nature (Lond.). 347:669-671.

63. Ernst, C.A., Y.J. Zhang, P.R. Hancock, B.J. Rutledge, C.L. Corless, and B.J. Rollins. 1994. Biochemical and biologic characterization of murine monocyte chemoattractant protein-1. J. Immunol. 152:3541-3549.

64. Davatelis, G., P. Tekamp-Olson, S.D. Wolpe, K. Hermsen, C. Luedke, C. Gallegos, D. Coit, J. Merryweather, and A. Cerami. Cloning and characterization of a cDNA for mutine macrophage inflammatory protein (MIP), a novel monokine with inflammatory and chemokinetic properties. J. Exp. Med. 167: 1939-1946.

65. Post, T.W., C.R. Bozic, M.E. Rothenberg, A.D. Luster, N. Gerard, and C. Gerard. 1995. Molecular characterization of two murine eosinophil $\beta$ chemokine receptors. J. Immunol. 155:5299-5305.

66. Luo, Y., J. Laning, S. Devi, J. Mak, T.J. Schall, and M.E. Dorf. 1994. Biologic activities of the murine b-Chemokine TCA3. J. Immunol. 153:4616-4624.

67. Ponath, P.D., S. Qin, T.W. Post, J. Wang, L. Wu, N.P. Gerard, W. Newman, C. Gerard, and C.R. Mackay. 1996. Molecular cloning and characterization of a human eotaxin receptor expressed selectively on eosinophils. J. Exp. Med. 183:2437-2448.

68. Mombaerts, P., J. Iacomini, R.S. Johnson, K. Herrup, S. Tonegawa, and V. Papaioannou. 1992. RAG-1-deficient mice have no mature B and T lympho- cytes. Cell. $68: 869-877$.

69. Gordon, J.R., and Galli, S. 1990. Mast cells as a source of both preformed and immunologically inducible TNF-alpha/cachectin. Nature (Lond.). 346:274-277.

70. Van Rooijen, N. 1989. The liposome-mediated macrophage "suicide" technique. J. Immunol. Methods. 124:1-21.

71. Begg, S., J. Radley, J. Pollard, O. Chisholm, and I. Bertoncello. 1993. Delayed hematopoietic development in op/op mice. J. Exp. Med. 177:237-242.

72. Lieschke, G.J., E. Stanley, D. Grail, G. Hodgson, V. Sinickas, J.A.M. Gall, R.A. Sinclair, and A.R. Dunn. 1994. Mice lacking both macrophage- and granulocyte-macrophage colony-stimulating factor have macrophages and coexistent osteopetrosis and severe lung disease. Blood. 84:27-35.

73. Walker, C., E. Bode, L. Boer, T.T. Hansel, K. Blaser, and J.C. Virchow Jr. 1992. Allergic and non-allergic asthmatics have distinct patterns of T-cell activation and cytokine production in peripheral blood and bronchoalveolar lavage. Am. Respir. Dis. 146:109-115.

74. Gavett, S.H., D.J. O'Hearn, X. Li, S.-K. Huang, F.D. Finkelman, and M Wills-Karp. 1995. Interleukin 12 inhibits antigen-induced airway hyperresponsiveness, inflammation, and Th2 cytokine expression in mice. J. Exp. Med. 182: $1527-1536$.

75. Corry, D.B., H.G. Folkesson, M.L. Warnock, D.J. Erle, M.A. Matthay, J.P. Wiener-Kronish, and R.M. Locksley. 1996. Interleukin 4, but not interleukin 5 or eosinophils, is required in a murine model of acute airway hyperreactivity. J. Exp. Med. 183:109-117.

76. Foster, P.S., S.P. Hogan, A.J. Ramsay, K.I. Matthaei, and I.G. Young. 1996. Interleukin 5 deficiency abolishes eosinophilia, airways hyperreactivity, and lung damage in a mouse asthma model. J. Exp. Med. 183:195-201.

77. Nakajima, H., I. Iwamoto, S. Tomoe, R. Matsumaura, H. Tomioka, K. Takatsu, and S. Yoshida. 1992. CD4 ${ }^{+}$T-lymphocytes and interleukin-5 mediate antigen-induced eosinophil infiltration into the mouse trachea. Am. Rev. Respir. Dis. 146:374-377.

78. Gavett, S.H., X. Chen, F. Kinkelman, and M. Wills-Karp. 1994. Depletion of murine $\mathrm{CD} 4^{+} \mathrm{T}$ lymphocytes prevents antigen-induced airway hyperreactivity and pulmonary eosinophilia. Am. J. Respir. Cell Mol. Biol. 10:587-593.

79. Hamelmann, E., A. Oshiba, J. Paluh, K. Bradley, J. Loader, T.A. Potter, G.L. Larsen, and E.W. Gelfand. 1996. Requirement for CD8 ${ }^{+}$T cells in the development of airway hyperresponsiveness in a murine model of airway sensitization. J. Exp. Med. 183:1719-1729.

80. Jia, G.-Q., J.A. Gonzalo, C. M. Lloyd, L. Kremer, L. Lu, C. Martinez-A, B.K. Wershil, and J.C. Gutierrez-Ramos. 1996. Distinct expression and function of the novel mouse chemokine MCP-5 in lung allergic inflammation. $J$. Exp. Med. 184:1939-1952. 